\title{
Applications and limitations of U-Th disequilibria systematics for determining ages of carbonate alteration minerals in peridotite
}

\author{
Evelyn M. Mervine ${ }^{\mathrm{a},{ }^{*}}$, Kenneth W. W. Sims ${ }^{\mathrm{b}}$, Susan E. Humphris ${ }^{\mathrm{c}}$, and Peter B. Kelemen ${ }^{\mathrm{d}}$
} Prepared for submission to Chemical Geology

${ }^{a}$ MIT/WHOI Joint Program, Geology and Geophysics Department, Woods Hole Oceanographic Institution, 266 Woods Hole Road, Woods Hole, MA 02543, USA, emervine@ whoi.edu

${ }^{\mathrm{b}}$ Geology and Geophysics Department, University of Wyoming, 1000 East University Avenue, Laramie, Wyoming 82071, USA, ksims7@uwyo.edu

${ }^{c}$ Geology and Geophysics Department, Woods Hole Oceanographic Institution, 266 Woods Hole Road, Woods Hole, MA 02543, USA, shumphris@whoi.edu

${ }^{\text {d} L a m o n t-D o h e r t y ~ E a r t h ~ O b s e r v a t o r y, ~} 61$ Route 9W, Palisades, NY 10964, USA, peterk@1deo.columbia.edu

*Corresponding author. Present address: De Beers Marine, DBM Gardens, Golf Park 2, Raapenberg Road, Pinelands, 7405, Cape Town, South Africa, Tel: +27 (0)21 6583224. Evelyn.Mervine@debeersgroup.com. 


\section{Abstract}

${ }^{238} \mathrm{U}-{ }^{234} \mathrm{U}-{ }^{230} \mathrm{Th}$ dating was conducted on carbonate alteration minerals in the peridotite layer of the Samail Ophiolite, Sultanate of Oman, in order to assess the applicability of U-series dating techniques to these types of Quaternary terrestrial carbonates and also to further constrain natural rates of carbonation of the peridotite. Due to their low $U$ concentrations and relatively high Th/U ratios, Samail carbonates are challenging to date with the ${ }^{230} \mathrm{Th}$ technique because of the sensitivity of ages to corrections for initial ${ }^{230} \mathrm{Th}$. Uncorrected ${ }^{230} \mathrm{Th}$ ages for Ca-rich travertines are consistently older than previously obtained ${ }^{14} \mathrm{C}$ ages. However, geologically reasonable initial ${ }^{230} \mathrm{Th}$ corrections bring the two sets of ages into concordance. This age concordance suggests that the travertines are generally closed systems, adding a level of credence to the reliability of previously obtained ${ }^{14} \mathrm{C}$ ages. In contrast, uncorrected ${ }^{230} \mathrm{Th}$ ages for $\mathrm{Mg}$-rich carbonate veins are generally younger than previously obtained ${ }^{14} \mathrm{C}$ ages. These young ages are interpreted in terms of remobilization of hexavalent $U$, which is subsequently

47 deposited as tetravalent $\mathrm{U}$ by reduced serpentinization fluids. Two $\mathrm{Mg}$-rich carbonate veins sampled at a roadcut have near-equilibrium $\left({ }^{230} \mathrm{Th} /{ }^{238} \mathrm{U}\right)$ and $\left({ }^{234} \mathrm{U} /{ }^{238} \mathrm{U}\right)$ values, which indicate that these veins are $>375,000$ years in age, consistent with their ${ }^{~}{ }^{14} \mathrm{C}$ dead" $(>50,000 \mathrm{yr} \mathrm{BP})$ ages. The variable young and old ages for these Mg-rich carbonate veins indicate that carbonation of the peridotite layer of the Samail Ophiolite is an ongoing process and that there

52 have been multiple generations of subsurface carbonate vein formation. Overall, this study provides insights into some of the challenges associated with applying U-series dating methods to Quaternary terrestrial carbonates, in particular carbonate alteration minerals in peridotites, and highlights some areas where there is room for improvement, such as obtaining better 56 constraints on the isotopic composition of admixed detritus, and also some advantages, such as

57 the ability to identify open system behavior not apparent from ${ }^{14} \mathrm{C}$ dating and stable $\mathrm{C}$ and $\mathrm{O}$ 58 isotopic analysis alone. 


\section{Introduction}

Determining timescales of the formation and preservation of carbonate alteration minerals in mantle peridotite is essential to better understand the role of this potentially important sink in the global carbon cycle and also to evaluate the feasibility of using artificially enhanced, in situ formation of carbonates in peridotite as a method for mitigating the buildup of anthropogenic $\mathrm{CO}_{2}$ emissions in the atmosphere (e.g. Seifritz, 1990; Lackner et al., 1995; Lackner, 2002; Kelemen and Matter, 2008; Matter and Kelemen, 2009; Kelemen et al., 2011). While natural carbonation of peridotite is commonly observed subaerially and on the seafloor (e.g. Trommsdorff and Evans, 1977; Trommsdorff et al., 1980; Ferry, 1995; Surour and Arafa, 1997; Kelley et al., 2001; Früh-Green et al., 2003; Ludwig et al., 2006, 2011; Kelemen and Matter, 2008; Matter and Kelemen, 2009; Power et al., 2009; Kelemen et al., 2011; Pronost et al., 2011; Beinlich and Austrheim, 2012; Harrison et al., 2013; Chavagnac et al., 2013a, b; Mervine et al., 2014), the natural rate of peridotite carbonation and therefore the rate of $\mathrm{CO}_{2}$ uptake via this alteration mechanism is poorly known (e.g. Wilson et al., 2006, 2009a, 2009b; Kelemen and Matter, 2008; Kelemen et al., 2011; Mervine et al., 2014). In part, this is because carbonate alteration minerals in peridotite are challenging to date. Several studies (e.g. Kelemen and Matter, 2008; Wilson et al., 2009b; Kelemen et al., 2011; Mervine et al., 2014) have employed ${ }^{14} \mathrm{C}$ dating, but this dating technique has a practical limit of only $\sim 50,000$ years. Use of the ${ }^{238} \mathrm{U}_{-}{ }^{234} \mathrm{U}_{\text {and }}{ }^{234} \mathrm{U}_{-}{ }^{230} \mathrm{Th}$ disequilibria dating techniques (which have practical dating limits of $\sim 1$ million years and $\sim 375,000$ years, respectively) and the $\mathrm{U}-\mathrm{Pb}$ dating technique (which is suitable for dating on timescales of millions of years) to investigate longer timescales of carbonation is limited by the generally low (ppb level) $\mathrm{U}$ concentrations of peridotites and their associated carbonate alteration minerals (e.g. Hanghøj et al., 2010; Bodinier and Godard, 2014). Carbonates formed in peridotites at the Lost City Hydrothermal Field, which is located off-axis 
84 of the mid-Atlantic Ridge, have been dated using U-Th disequilibria techniques (Ludwig et al.,

85 2011). However, these carbonates have high U concentrations (ppm level) due to contribution of

$86 \mathrm{U}$ from seawater (Ludwig et al., 2011). Historically, little work has been done to apply the U-Pb

87 dating technique to carbonates although recently there has been some development in this field, with a focus on dating of speleothem samples with high $\mathrm{U}$ and low common $\mathrm{Pb}$ concentrations (e.g. Rasbury and Cole, 2009; Woodhead and Pickering, 2012; Hellstrom and Pickering, 2015). Furthermore, while some carbonates, particularly corals and speleothems, are routinely dated with the U-Th disequilibria methods (e.g. Edwards et al., 2003), dating of terrestrial

92 carbonates with these techniques can be challenging due to the significant presence of admixed detritus. Unlike most corals and speleothems, terrestrial carbonates are usually affected by the 94 presence of initial ${ }^{230} \mathrm{Th}$ and, to a lesser extent, by ${ }^{234} \mathrm{U}$ and ${ }^{238} \mathrm{U}$ contributed by detrital material (e.g. Bischoff and Fitzpatrick, 1991; Luo and Ku, 1991; Kaufman, 1993). This detritus is often fine-grained and intergrown with the carbonate, making physical separation very difficult (e.g.

$97 \mathrm{Ku}$ and Liang, 1984; Bischoff and Fitzpatrick, 1991; Luo and Ku, 1991). Various approaches 98 have been attempted over the years to account for detrital ${ }^{230} \mathrm{Th},{ }^{234} \mathrm{U}$, and ${ }^{238} \mathrm{U}$ in terrestrial 99 carbonates, including light acid leaching, separating the carbonate material from the admixed detritus, and pseudoisochron methods for determining the composition of incorporated detritus

101 (e.g. Osmond et al., 1970; Schwarcz and Latham, 1989; Przybylowicz et al., 1991; Bischoff and 102 Fitzpatrick, 1991; Luo and $\mathrm{Ku}, 1991)$. However, these techniques have had limited success. In 103 most cases, employing total sample dissolutions with corrections for detrital inputs is the most 104 robust way to obtain U-Th disequilibria ages for terrestrial carbonates (e.g. Kaufman, 1993;

105 Ludwig and Titterington, 1994; Edwards et al., 2003). However, terrestrial carbonates with low $106 \mathrm{U}$ concentrations and high $\mathrm{Th} / \mathrm{U}$ ratios, such as carbonate alteration products formed in 
107 peridotites, can be challenging to date with U-Th disequilibria methods since the ages are highly 108 sensitive to detrital corrections. In this study we examine the applications and limitations of using U-Th disequilibria 110 methods to date carbonate alteration minerals that formed in peridotites of the Samail Ophiolite, 111 Sultanate of Oman (Figure 1). The Samail Ophiolite is one of the largest and best-exposed 112 ophiolites in the world (Glennie et al., 1973, 1974; Coleman, 1977, 1981; Lippard et al., 1986;

113 Nicolas et al., 2000) and is thus an excellent location for investigating natural rates of carbonate 114 formation in peridotite. The goal of this study was to determine ${ }^{238} \mathrm{U}-{ }^{234} \mathrm{U}$ and ${ }^{234} \mathrm{U}-{ }^{230} \mathrm{Th}$ ages 115 and age limits for Samail carbonates in order to further assess the range of ages of carbonate 116 alteration minerals in the peridotite layer of the Samail Ophiolite. This study builds upon 117 previous ${ }^{14} \mathrm{C}$ dating and stable $\mathrm{C}$ and $\mathrm{O}$ isotope analyses of Samail carbonates, which are 118 presented in Mervine et al. (2014) and also in Clark and Fontes (1990), Clark et al. (1992), 119 Kelemen and Matter (2008), and Kelemen et al. (2011). Because these Quaternary terrestrial 120 carbonates contain significant admixed fine-grained detritus, we underook methods to: (1.) 121 attempt to separate the aluminosilicate detritus from the carbonate or (2.) accurately correct for 122 the effect the detritus is having on the ${ }^{238} \mathrm{U}-{ }^{234} \mathrm{U}-{ }^{230} \mathrm{Th}$ isotope systematics of the carbonate 123 minerals. Comparing the ${ }^{238} \mathrm{U}_{-}{ }^{234} \mathrm{U}_{\text {and }}{ }^{234} \mathrm{U}_{-}{ }^{230} \mathrm{Th}$ ages and age limits determined for the Samail 124 carbonates with previously published ${ }^{14} \mathrm{C}$ ages on the same samples (Mervine et al., 2014) 125 enables us to more carefully scrutinize the reliability of ages obtained with both dating systems 126 and to further constrain timescales of natural carbonation of Samail Ophiolite peridotites.

\section{Background}




\subsection{Terrestrial carbonates in the Samail Ophiolite}

The Samail Ophiolite ranges from approximately 50 to $100 \mathrm{~km}$ in width and extends for greater than $500 \mathrm{~km}$ (e.g. Lippard et al., 1986; Nicolas et al., 2000). The ophiolite consists of several uplifted, thrust-bounded blocks (nappes) of oceanic crust and mantle that were obducted at $\sim 80$ to $95 \mathrm{Ma}$ on top of autochthonous shelf carbonate rocks (the Hajar Supergroup) and parautochthonous continental slope carbonate rocks (the Sumeini Group), which rest on top of pre-Permian crystalline basement (Coleman, 1981; Lippard et al., 1986; Searle and Cox, 1999, 2002). These nappes consist of $\sim 4$ to $7 \mathrm{~km}$ of crustal rocks (layered gabbros, sheeted dikes, and volcanics, including pillow lavas) and $\sim 8$ to $12 \mathrm{~km}$ of upper mantle, primarily harzburgite (Glennie et al., 1973, 1974; Coleman, 1981; Lippard et al., 1986; Nicolas et al., 2000). Abundant carbonate veins as well as calcite-rich travertines are found throughout the peridotite layer of the ophiolite (e.g. Neal and Stanger, 1984, 1985; Clark and Fontes, 1990; Clark et al., 1992; Kelemen and Matter, 2008; Kelemen et al., 2011; Chavagnac et al., 2013 a, b; Mervine et al., 2014).

This study focuses on two types of carbonate alteration products that form in the peridotite layer of the Samail Ophiolite: (1.) travertine precipitated from high $\mathrm{pH}$ springs (Clark and Fontes, 1990; Clark et al., 1992; Kelemen and Matter, 2008; Kelemen et al., 2011; Paukert et al., 2012; Chavagnac et al., 2013a, 2013b; Mervine et al., 2014) and (2.) carbonate veins that form in situ in partially hydrated (serpentinized) peridotite (Kelemen and Matter, 2009; Kelemen et al., 2011; Streit et al., 2012; Mervine et al., 2014). These carbonates are thought to form as a result of low temperature alteration of peridotite through interaction with meteoric water (Figure

2) (e.g. Barnes et al., 1967, 1978; Barnes and O’Neil, 1969, 1971; Neal and Stanger, 1985; Bruni et al., 2002; Cipolli et al., 2004; Kelemen et al., 2011). When meteoric water weathers partially 
153 serpentinized peridotite, $\mathrm{Mg}^{2+}-\mathrm{HCO}_{3}{ }^{-}$rich waters (known as "Type I" waters) are formed. As 154 these waters percolate deeper into peridotite bedrock where they are no longer in equilibrium 155 with the atmosphere, they precipitate Mg-rich carbonates, serpentines, and clays. As a result of 156 this precipitation and other reactions in the subsurface, the waters transform into $\mathrm{Ca}^{2+}-\mathrm{OH}^{-}$ 157 waters (known as "Type II" waters) that have very high $\mathrm{pH}$ (10 to 12) and low $\mathrm{Mg}, \mathrm{C}$, and 158 oxygen fugacity (Eh approximately -200 mV) (Neal and Stanger, 1983, 1984, 1985; Clark and 159 Fontes, 1990; Kelemen and Matter, 2008; Kelemen et al., 2011; Paukert et al., 2012; Chavagnac 160 et al., 2013a, b). When Type II waters return to the surface as hyperalkaline springs, they rapidly 161 react with atmospheric $\mathrm{CO}_{2}$ to precipitate calcite-rich travertines (e.g. Clark and Fontes, 1990; 162 Clark et al., 1992; Kelemen and Matter, 2008; Paukert et al., 2012; Chavagnac et al., 2013a, b; 163 Mervine et al., 2014).

The calcite-rich travertines (Figure 3, Panels A to C) are precipitated from the 165 hyperalkaline springs found throughout the Samail Ophiolite, predominantly in the peridotite 166 layer and concentrated along the basal thrust of the ophiolite as well as along the crust-mantle 167 boundary (Neal and Stanger, 1984, 1985; Clark and Fontes, 1990; Clark et al., 1992; Dewandel 168 et al., 2003, 2004, 2005; Kelemen and Matter, 2008; Kelemen et al., 2011; Paukert et al., 2012; 169 Chavagnac et al., 2013a, b). At these springs, thick travertine deposits (up to several meters, on 170 average $\sim 1$ to $2 \mathrm{~m}$ ) form on top of peridotite, which is highly fractured with abundant carbonate171 serpentine veins. Turquoise-blue alkaline pools lined with white carbonate precipitate are a 172 feature of many hyperalkaline springs. Browner, more weathered (and generally older) travertine 173 deposits are often found upslope and to the side of the actively precipitating travertine deposits 174 (Kelemen and Matter, 2008; Mervine et al., 2014). 
The carbonate veins (Figure 3, Panels D to $\mathrm{H}$ ) form in situ in the peridotite and, to a 176 lesser extent, in the gabbro and basalt layers of the ophiolite (Kelemen and Matter, 2008;

177 Kelemen et al., 2011; Mervine et al., 2014). Carbonate veins adjacent to surface travertine 178 deposits are Ca-rich and similar in composition to the travertines. Carbonate veins sampled far 179 from travertines are generally $\mathrm{Mg}$-rich and presumably formed in the deeper subsurface during 180 the transformation of Type I waters to Type II waters. The Mg-rich carbonate veins are 181 predominately composed of magnesite and dolomite, range in size from a few millimeters to 182 several meters thick, and can extend for hundreds of meters (Kelemen and Matter, 2008; 183 Kelemen et al., 2011; Mervine et al., 2014). The Mg-rich carbonate veins are often intergrown 184 with serpentine veins.

\subsection{Previous dating of carbonate alteration minerals in peridotite in the Samail Ophiolite}

Carbonate alteration minerals formed in the peridotite layer of the Samail Ophiolite have been previously dated by ${ }^{14} \mathrm{C}$, with ages reported in Clark and Fontes (1990), Clark et al. (1992), Keleman and Matter (2008), Kelemen et al. (2011), and Mervine et al. (2014). Clark and Fontes (1990) and Clark et al. (1992) dated 50 travertines and travertine veins sampled in the vicinity travertine veins varied in age from $>$ modern (post-1950) to $\sim 35,000 \mathrm{yr}$ BP, with one sample ${ }^{\text {"14 }} \mathrm{C}$

193 dead" (older than the $\sim 50,000$ year limit of ${ }^{14} \mathrm{C}$ dating). Kelemen and Matter (2008) and

194 Kelemen et al. (2011) dated 60 carbonates, both travertines and Mg-rich carbonate veins, from 195 numerous locations throughout the southern $\sim 2 / 3$ of the ophiolite. Similar to the previous studies 196 in the Nizwa area, they found that the travertines varied in age from >modern to $\sim 40,000 \mathrm{yr}$ BP. 197 They also found that the $\mathrm{Mg}$-rich carbonate veins had an average ${ }^{14} \mathrm{C}$ age of $\sim 26,000 \mathrm{yr} \mathrm{BP}$, an 
198 important observation since previously many of these veins were believed to be tens of millions 199 of years old. Only two of their samples were ${ }^{14} \mathrm{C}$ dead. Mervine et al. (2014) obtained ${ }^{14} \mathrm{C}$ ages 200 for an additional $\sim 100$ Samail carbonates, including several layered travertine terrace sequences. 201 Evaluating all available ${ }^{14} \mathrm{C}$ data, Mervine et al. (2014) concluded that the travertines range in 202 age from $>$ modern to $>45,000 \mathrm{yr}$ BP in age and that between $\sim 30,000$ and $\sim 45,000 \mathrm{yr}$ BP the 203 travertine deposition rate was $\sim 0.1$ to $0.3 \mathrm{~mm} / \mathrm{yr}$ for the four travertine sequences analyzed. 204 Furthermore, they found that new travertine ${ }^{14} \mathrm{C}$ ages filled in previously observed "gaps" in the 205 Clark and Fontes (1990) dataset, implying that travertine deposition has been fairly continuous 206 and not necessarily controlled by climatic variations, as was previously hypothesized by Clark 207 and Fontes (1990). Notably, Mervine et al. (2014) observed that a significant proportion of Mg208 rich carbonate veins sampled at three roadcuts were ${ }^{14} \mathrm{C}$ dead. A location-weighted average 209 indicates that $\sim 40 \%$ of $\mathrm{Mg}$-rich carbonate veins sampled at roadcuts are ${ }^{14} \mathrm{C}$ dead. In contrast, no 210 Mg-rich carbonate veins sampled at outcrops (i.e. on the natural weathering surface of the 211 peridotite) are ${ }^{14} \mathrm{C}$ dead. Mervine et al. (2014) concluded that there have been multiple 212 generations of $\mathrm{Mg}$-rich carbonate vein formation and that this vein formation continues to the 213 present day. Furthermore, they speculated that some of the apparent ${ }^{14} \mathrm{C}$ ages for $\mathrm{Mg}$-rich 214 carbonate veins could be affected by open system behavior, such as dissolution and re215 precipitation. Overall, the ${ }^{14} \mathrm{C}$ data indicate that carbonation of the peridotite layer of the Samail 216 Ophiolite is a recent and on-going process and not exclusively an ancient one.

\section{Methods}




\subsection{Sample descriptions}

Sample descriptions are given in Table 1. Carbonates were collected from four locations (Figure 1) of travertine deposition (Qafeefah Travertine, Misht Travertine, Wadi Uqaybah Travertine, and Wadi Sudari Travertine), from three roadcuts exposing carbonate veins in peridotite (Qafeefah Roadcut, Fanja Roadcut, and Al-Wuqbah Roadcut), and from one campsite located on the natural peridotite weathering surface and containing abundant carbonate veins exposed in outcrop (Wadi Sudari Campsite). All carbonates analyzed for U and Th were also dated with ${ }^{14} \mathrm{C}$ and analyzed for $\delta^{13} \mathrm{C}$ and $\delta^{18} \mathrm{O}$, the results of which have been previously reported in Mervine et al. (2014). Three water samples were collected from hyperalkaline pools at Wadi Sudari Travertine, Misht Travertine, and Wadi Dima (near Qafeefah, see Figure 1) during January 2009 by Jürg Matter (University of Southampton). The water samples (500 mL) were filtered and acidified with ultrapure $\mathrm{HNO}_{3}$ and were later analyzed for $\mathrm{U}$ and $\mathrm{Th}$ concentrations.

Three types of surficial travertines were analyzed for $U$ and Th: (1.) recently-formed travertine precipitates collected from the bottoms of hyperalkaline pools (two samples), (2.) travertine terraces (four samples), and (3.) travertine "pseudospeleothems" (two samples), which are speleothem-like formations that have developed in overhangs, such as underneath travertine terraces. Note that these features are not true speleothems because they were not formed within caves. Also note that travertine terrace sample OM09-109C-MS is part of a younger travertine terrace forming between weathered, older travertine terraces; these travertines were distinguished as "channel-filling travertines" in Mervine et al. (2014). In addition, U and Th measurements were obtained for one Ca-rich travertine vein. 
244 of this study, these veins have been divided into "outcrop veins" (sampled from the natural

245 peridotite weathering surface) and "roadcut veins" (sampled at roadcuts). Both types of veins are

246 interpreted to have formed in the deeper subsurface; however, the roadcut veins are generally

247 less weathered than the outcrop veins, which are often partially eroded. U and Th concentration

248 measurements were also obtained for two serpentine mineral fractions that were separated out of 249 intergrown carbonate-serpentine veins sampled at roadcuts.

250 Finally, $\mathrm{U}$ and Th measurements were obtained for two sediment samples, which are a

251 potential source of detritus in the carbonates. These sediment samples were collected from small

252 wadis or valleys adjacent to the carbonates sampled at Fanja Roadcut and Wadi Uqaybah

253 Travertine. There is no significant soil formation at any of the carbonate sampling locations, so

254 these sediments consist of loose detritus that contains fragments of peridotite and carbonate as

255 well as aeolian particles.

256

$257 \quad 3.2$ Geochemical analyses

258 Carbonates selected for $U$ and Th analysis were crushed using a jaw crusher and then

259 purified through magnetic separation and hand picking. Many of the carbonate veins consist of 260 multiple minerals (e.g. magnesite, calcite, dolomite, serpentine, brucite). Whenever possible, 261 monomineralic (or nearly so) separates were prepared, and their purity was evaluated by powder 262 X-ray diffraction (XRD) analysis at Woods Hole Oceanographic Institution using a Philips 263 Analytical PW1830 XRD machine. Mineral identification was conducted using the International 264 Center for Diffraction Data Powder Diffraction File. While large fragments of peridotite and 265 serpentine were easily removed through magnetic separation and hand picking, fine-grained 
266 aluminosilicate material incorporated into the travertines and, to a lesser extent, into the 267 subsurface carbonate veins was impossible to remove through physical separation. Note that the 268 two recently formed travertine precipitates (OM09-8COPS-MS and OM09-10COPS-MS) were 269 not purified (aside from removing large, obvious peridotite clasts) due to their fine-grained 270 nature.

271 For travertines, approximately 1 to $2 \mathrm{~g}$ of material was required for analysis. For $\mathrm{Mg}$-rich 272 carbonate veins, approximately 20 to $30 \mathrm{~g}$ of material was required because of their extremely 273 low $\mathrm{U}$ and $\mathrm{Th}$ concentrations. For select $\mathrm{Mg}$-rich carbonate veins as well as the two serpentine 274 mineral separates, 1 to $2 \mathrm{~g}$ of material was first analyzed for $\mathrm{U}$ and Th concentrations in order to 275 identify samples that were most promising for isotopic analysis (i.e. had the highest $U$ 276 concentrations). For the sediments, 2 to $10 \mathrm{~g}$ of a bulk powder was analyzed for each sample.

277 Carbonates selected for ${ }^{230} \mathrm{Th}$ analyses were completely dissolved using $\mathrm{HNO}_{3}, \mathrm{HF}$, $278 \mathrm{HClO}_{4}$, and $\mathrm{H}_{3} \mathrm{BO}_{3}$. To investigate the behavior of samples during dissolution and also the nature 279 of the incorporated aluminosilicate detritus, separate weak $\mathrm{HNO}_{3}$ leaches were carried out for 280 select samples. The aluminosilicate residues left behind by these weak $\mathrm{HNO}_{3}$ leaches were also 281 dissolved and analyzed separately. A progressive dissolution experiment was carried out on one 282 travertine sample (OM09-107C-MS). The dissolution experiments are discussed in detail in the 283 Supplementary Information. In brief, the dissolution experiments indicate that both elemental 284 and isotopic fractionation of $U$ and Th occurs during partial dissolution of Samail carbonates. 285 This fractionation is most significant for the surface travertines, which incorporate higher 286 amounts of aluminosilicate detritus than the subsurface carbonate veins. The observed 287 fractionation as a result of partial dissolutions reinforces the need to employ a total dissolution 
288 approach for ${ }^{230} \mathrm{Th}$ dating of terrestrial carbonates that contain significant admixed detritus (e.g. 289 Bischoff and Fitzpatrick, 1991; Luo and Ku, 1991).

After dissolution, $\mathrm{U}$ and Th were purified using two columns (see details in Ball et al., 2912008 and Sims et al., 2008a). The first was a nitric anion column that removes U and Th from the 292 rock matrix. The second was a hydrochloric anion column that separates U from Th. For large 293 samples, U and Th were first co-precipitated with Fe hydroxide. For the Fe hydroxide 294 precipitation, $3.5 \mathrm{mg}$ of an ultrapure Fe ICP standard manufactured by Ricca Chemical was 295 added to each sample (see Edwards et al., 1986 for discussion of the Fe-hydroxide precipitation 296 step).

$\mathrm{U}$ and Th concentrations were measured by isotope dilution ICP-MS using ${ }^{229} \mathrm{Th}$ and ${ }^{233} \mathrm{U}$ 298 spikes. The isotope dilution measurements were carried out on a Thermo Element2 mass 299 spectrometer at Woods Hole Oceanographic Institution following procedures detailed in Sims et 300 al. (2008a). U and Th isotopes were measured on chromatographically separated $\mathrm{U}$ and Th 301 aliquots on separate days by MC-ICP-MS on the ThermoFinnegan NEPTUNE at Woods Hole 302 Oceanographic Institution using techniques described in Ball et al. (2008) and Sims et al. (2008a, 303 2008b). When measuring Th isotopes, ${ }^{230}$ Th is in the center SEM using the RPQ high abundance 304 sensitivity filter, and ${ }^{232} \mathrm{Th}$ is measured on an up-mass Faraday. Th isotope mass bias and SEM 305 Faraday yield was corrected for by sample standard bracketing using a ${ }^{230} \mathrm{Th} /{ }^{232} \mathrm{Th}$ atom ratio of $30611.380 \pm 0.170 \times 10^{-6}$ for IRMM 35 (see Sims et al., 2008b for details). For U isotopic 307 measurements, ${ }^{234} \mathrm{U}$ was measured on the center SEM, and ${ }^{235} \mathrm{U}$ and ${ }^{238} \mathrm{U}$ were measured on up308 mass Faradays. U isotopes were corrected for mass bias using both an internal correction and 309 assuming the samples ${ }^{235} \mathrm{U} /{ }^{238} \mathrm{U}=0.0072527$ (Cheng et al, 2000) and an external correction 310 using NBL U010 for a mass bias and SEM-Faraday yield using the Richter and Goldberg (2003) 
311 values ${ }^{235} \mathrm{U} /{ }^{238} \mathrm{U}=0.0101382$ and ${ }^{234} \mathrm{U} /{ }^{238} \mathrm{U}=5.4483 \times 10^{-5}$ (see Ball et al., 2008 for details). For

312 a matrix matched quality assurance standard, the carbonate standard (JCp-1) was analyzed for U

313 and Th concentrations and isotopes (Tables 2 and 3). In addition, a large compilation of $U$ and

314 Th concentration and isotopic ratio measurements for five synthetic Th standards (IRMM 35,

315 IRMM36, UCSC ThA, WUN, OU ThU) and six rock standards (UCSC TML, Icelandic ATHO,

316 USGS BCR2, USGS W2, USGS BHVO-2, and LV18) that were analyzed at the same time of

317 this Oman study can be found in Sims et al. (2008a), which represents a concerted international

318 effort of six labs (WHOI; UCSC; LLNL; UI Urbana; GEOMOC, AU; Bristol, UK) to cross

319 calibrate these U-series standards. The same instrumentation, methods, and ${ }^{229} \mathrm{Th}$ and ${ }^{233} \mathrm{U}$ spikes

320 were used in both this study and in Sims et al. (2008a). Total procedural blanks, including the

321 acid used for sample introduction, are typically less than $<4$ pg ( $1 \times 10^{10}$ atoms) for ${ }^{238} \mathrm{U}$ and $<3$

322 pg $\left(7 \times 10^{9}\right.$ atoms $)$ for ${ }^{232} \mathrm{Th}$. Blank levels for ${ }^{234} \mathrm{U}$ and ${ }^{230} \mathrm{Th}$ are un-measureable but are 323 approximately $10^{-4}$ of ${ }^{238} \mathrm{U}$ and $10^{-5}$ of ${ }^{232} \mathrm{Th}$, respectively.

\section{4. Results}

$326 \quad 4.1$ Mineralogy

The results of X-ray diffraction analysis of powdered samples are presented in Table 1.

328 Minerals were identified as "major" or "minor" but were not further quantified. The mineralogy of the Samail carbonates is discussed in detail in Mervine et al. (2014).

330 In brief, the travertine samples consist predominately of calcite with trace quantities of unidentified clay minerals. One recently formed travertine precipitate (OM09-8COPS-MS) also

332 contains minor aragonite and possibly hydromagnesite. The other recently formed travertine 333 precipitate (OM09-12S-MS) contains trace quartz, possibly from aeolian sand incorporated into 
334 the sample. The Mg-rich subsurface carbonate veins consist primarily of magnesite or dolomite 335 except for one sample (OM10-84C-MG), which consists primarily of brucite. near Fanja Roadcut (OM09-8S-MS) consists primarily of lizardite with minor quartz, dolomite, magnesite, and calcite. The second sample collected near Wadi Uqaybah Travertine (OM09-12SMS consists primarily of quartz and calcite with minor chrysotile, dolomite, enstatite, and possibly aragonite. The difference in mineralogy reflects the different detrital inputs from the nearby environment and also from aeolian sources at these two locations.

\section{$4.2 U$ and Th concentrations}

Samail carbonates have $\mathrm{U}$ and $\mathrm{Th}$ concentrations ranging over several orders of magnitude from $<1 \mathrm{ppb}$ to $\sim 1 \mathrm{ppm}$ (Table 2 and Figure 4). The travertine terraces and wadi 346 sediments have the highest $\mathrm{U}$ and Th concentrations, ranging from $\sim 0.1$ to $\sim 1 \mathrm{ppm}$ for both $\mathrm{U}$ 347 and $\mathrm{Th}$. The Mg-rich carbonate veins have $\mathrm{U}$ and Th concentrations ranging from $<1 \mathrm{ppb}$ to $\sim 10$ $348 \mathrm{ppb}$, three or four orders of magnitude lower than most of the travertine $\mathrm{U}$ and Th concentrations. 349 Sample OM09-63C-MS, an Mg-rich carbonate vein, has U and Th concentrations comparable to 350 the total procedural blank and thus below detection limit. The two serpentine mineral separates 351 (from serpentine-carbonate veins) have very low ( $<1 \mathrm{ppb}) \mathrm{U}$ and Th concentrations comparable 352 with those of the Mg-rich carbonate veins. The three hyperalkaline $(500 \mathrm{~mL})$ water samples 353 analyzed by isotope dilution were well below the instrumental detection limits for $\mathrm{U}$ and $\mathrm{Th}$,

354 which are $\sim 1$ ppt. Reproducibility of $U$ and Th concentration measurements for JCp-1 $(n=4)$ is 355 better than the propagated analytical error of the individual measurements. The reproducibility of 356 the travertine samples and $\mathrm{Mg}$ carbonate samples is also quite good with the exception of OM09- 
47C-MS, which is likely due to this sample's low U and Th concentrations and potential for

358 heterogeneity from fine-grained admixed material.

\section{$4.3 U$ and Th isotopes}

$\mathrm{U}$ and Th isotopic data are presented in Table 3. Note that in the tables, and throughout 362 this paper, parentheses indicate activities. Due to low $U$ and Th concentrations, only a subset of 363 the samples analyzed for $U$ and Th concentrations could be analyzed for $U$ and Th isotopes.

Many of the Samail carbonates are out of equilibrium with respect to $\left({ }^{230} \mathrm{Th} /{ }^{238} \mathrm{U}\right.$ ) (Figure

5). Samples with $\left({ }^{230} \mathrm{Th} /{ }^{238} \mathrm{U}\right)=1$ plot on the equiline, indicating isotopic equilibrium. Four of the Mg-rich carbonate outcrop veins, two of the travertine terraces, and the travertine vein have $\left({ }^{230} \mathrm{Th} /{ }^{238} \mathrm{U}\right)<1$ and thus have ${ }^{238} \mathrm{U}$ excesses. One travertine terrace sample, the two travertine pseudospeleothems, the two recently-formed travertine precipitates, one of the $\mathrm{Mg}$-rich carbonate outcrop vein samples, four $\mathrm{Mg}$-rich carbonate roadcut vein samples, and the two sediment samples fall very close to the equiline.

Many of the Samail carbonates are also out of equilibrium with respect to $\left({ }^{234} \mathrm{U} /{ }^{238} \mathrm{U}\right)$

372 (Figure 6). The travertine terrace samples, recently formed travertine precipitates, and travertine

373 pseudospeleothems all have ${ }^{234} \mathrm{U}$ excesses with $\left({ }^{234} \mathrm{U} /{ }^{238} \mathrm{U}\right)$ values ranging from 1.118 to 1.255 .

374 However, the travertine vein sample plots on the other side of the equiline with a $\left({ }^{234} \mathrm{U} /{ }^{238} \mathrm{U}\right)$ 375 value of 0.832 , which may indicate that the hyperalkaline Type II fluids from which this sample 376 was precipitated reacted with material that has $\operatorname{low}{ }^{234} U /{ }^{238} U$ due to prior water-rock interaction.

377 The Mg-rich carbonate outcrop vein samples have a fairly narrow range of $\left({ }^{234} \mathrm{U} /{ }^{238} \mathrm{U}\right)$ values of 378 1.187 to 1.237.The Mg-rich carbonate roadcut vein samples have lower $\left({ }^{234} \mathrm{U} /{ }^{238} \mathrm{U}\right)$ values than 379 the outcrop vein samples, ranging from 0.998 to 1.123 . Two of the roadcut vein samples have 
380 near-equilibrium $\left({ }^{234} \mathrm{U}^{238} \mathrm{U}\right)$ values of 0.998 (Sample OM09-58C-MS) and 1.010 (Sample

381 OM09-57C-MS). Sediment sample OM09-8S-MS plots just above the equiline with $\left({ }^{234} \mathrm{U} /{ }^{238} \mathrm{U}\right)$

$382=1.032$ while sediment sample OM09-12S-MS, which contains significant calcite that likely

383 derives from nearby travertines, has higher $\left({ }^{234} U /{ }^{238} U\right)=1.102$, which approaches the values

384 observed in the surface travertines.

385 There is a large range of $\left({ }^{230} \mathrm{Th} /{ }^{232} \mathrm{Th}\right)$ values observed in the Samail carbonates and 386 sediments (Figure 7). Most samples have $\left({ }^{230} \mathrm{Th} /{ }^{232} \mathrm{Th}\right.$ ) values that fall in the range of $\sim 0$ to 6 . 387 However, the Mg-rich carbonate roadcut vein sample OM09-57C-MS has $\left({ }^{230} \mathrm{Th} /{ }^{232} \mathrm{Th}\right)=$ 38830.515.

390 5. Discussion

$391 \quad 5.1$ Systematics of $U$ and Th in Samail carbonates and sediments

$392 \quad$ 5.1.1 Origin of variable $\mathrm{U}$ and Th concentrations

The travertine samples, particularly the surface travertine samples, have the highest $\mathrm{U}$

394 and Th concentrations (Figure 4). The high U and Th concentrations of the travertines are likely

395 a result of incorporation of a significant amount of aluminosilicate detritus. There are multiple

396 lines of evidence that support this interpretation. First, while the higher U concentrations of the

397 travertines could be explained by $\mathrm{U}$ enrichment in fluids due to low water/rock ratios, the Th

398 concentrations can only be explained by the incorporation of detritus since Th is insoluble under

399 almost all conditions and is believed to be insoluble in both the Type I and the Type II waters

400 flowing through Samail peridotite (e.g. Langmuir and Herman, 1980; Porcelli and Swarzenski,

401 2003). Second, light acid leaches of travertine samples (see Supplementary Information) leave

402 behind significant aluminosilicate detritus, which has higher $U$ and Th concentrations than the 
carbonate material dissolved during the light acid leach. In contrast, most of the Mg-rich carbonate vein samples do not leave behind significant aluminosilicate residues after light acid leaches. Third, the $\mathrm{U}$ and Th concentrations of the travertine vein sample (OM09-84C-MS), which formed in the subsurface and likely incorporated less detritus, are lower than the other travertines. Finally, the travertine samples have $\mathrm{U}$ and Th concentrations that are comparable to the wadi sediments, which are likely sources of detritus.

Since the travertine samples incorporate significant detritus, constraining the composition of this component is essential to correct for detrital Th in the ${ }^{230} \mathrm{Th}$ age calculations. While fragments of serpentine and altered peridotite are observed in the travertines, these cannot be the only sources of detritus in the travertine samples because the travertine terrace samples have $\mathrm{U}$ and Th concentrations that are much higher than those measured in serpentine and partially serpentinized peridotites (Figure 4; peridotite data from Hanghøj et al., 2010). However, the two wadi sediments have $\mathrm{U}$ and $\mathrm{Th}$ concentrations that are comparable with those of the travertine terrace samples. The wadi sediments contain serpentine and enstatite, which likely originate from local peridotite bedrock (Table 1). They also contain significant modal quartz, which is most likely aeolian in origin, and significant carbonate minerals, such as calcite, dolomite, and magnesite. The magnesite likely originates from local magnesite veins in peridotite. However, the calcite and dolomite could originate from local carbonate alteration products in peridotite, such as weathered travertines, and from non-local carbonates transported by wind. For example, aeolian carbonate could originate from the Cretaceous Natih formation, which has $\mathrm{U}$ concentrations up to $\sim 9$ ppm (Figure 4; Natih carbonate data from Fleitmann et al., 2003). The two pseudospeleothems also have lower $\mathrm{U}$ and Th concentrations than the travertine terrace samples. This is likely because the formation beneath overhangs and the fine-grained texture of 
426 these pseudospeleothems reduces the amount of detritus that they incorporate. The low $U$

427 concentrations of the Mg-rich carbonate vein samples reflect the low $\mathrm{U}$ concentrations of the

428 peridotites (e.g. Hanghøj et al., 2010) that are altering to form these carbonates, and low U

429 concentrations in the reacting fluids (Figure 4).

\subsubsection{Systematics of $U$ and Th isotopes}

The Samail carbonates and sediments either have ${ }^{238} \mathrm{U}$ excesses or fall on the equiline of

433 the $\left({ }^{230} \mathrm{Th} /{ }^{232} \mathrm{Th}\right)$ versus $\left({ }^{238} \mathrm{U} /{ }^{232} \mathrm{Th}\right)$ plot (Figure 5). During initial precipitation from fluids,

434 Samail carbonates should have ${ }^{238} \mathrm{U}$ excesses. Over time, as the ${ }^{238} \mathrm{U}$ decay chain returns to 435 equilibrium, the isotopic compositions of the carbonates will move toward the equiline. After 436 approximately 375,000 years (5 times the half-life of ${ }^{230} \mathrm{Th}$, which equates to an uncertainty of $4373 \%$ in $\left.\left({ }^{230} \mathrm{Th} /{ }^{238} \mathrm{U}\right)\right)$, the isotopic compositions of the carbonate samples will plot on the equiline.

438 Thus, one interpretation is that the carbonate samples which plot on or close to the equiline (five 439 travertines, one $\mathrm{Mg}$-rich carbonate outcrop vein sample, and four $\mathrm{Mg}$-rich carbonate roadcut 440 veins sample) are 375,000 years or older in age. This interpretation may be valid for the 441 carbonate veins, which incorporate lower amounts of aluminosilicate detritus, but may not be 442 valid for the surface travertines.

As discussed previously, the travertine samples likely contain significant aluminosilicate 444 detritus, which explains their elevated $U$ and Th concentrations relative to the subsurface 445 carbonates. Therefore, travertine samples that plot near or on the $\left({ }^{230} \mathrm{Th} /{ }^{232} \mathrm{Th}\right)$ versus $446 \quad\left({ }^{238} \mathrm{U} /{ }^{232} \mathrm{Th}\right)$ equiline could either: (1.) be $\sim 375,000$ years or older in age or (2.) have 447 incorporated a significant quantity of equilibrium (or near-equilibrium) detritus that overwhelms 448 the isotopic signature of the pure travertine. The second explanation is favored since the two 
449 recently formed travertine precipitates, which have $>$ modern (post-1950) ${ }^{14} \mathrm{C}$ ages (Mervine et

450 al., 2014), fall on the equiline. These precipitates are known to have formed very recently, so old

$451{ }^{230}$ Th ages for these samples can be rejected. Therefore, these samples must have incorporated

452 significant near-equilibrium detritus, such as wadi sediments, two samples of which (OM09-8S-

453 MS and OM09-12S-MS) fall close to the equiline. The isotopic compositions of the other

454 travertine samples are also likely affected by the incorporation of aluminosilicate detritus. The

455 fact that the two wadi sediment samples plot close to the equiline is not unexpected. Most

456 aluminosilicate detritus (see the data compilation in the Supplementary Information) falls on the

457 equiline or has slight ${ }^{230} \mathrm{Th}$ excesses on a $\left({ }^{230} \mathrm{Th} /{ }^{232} \mathrm{Th}\right)$ versus $\left({ }^{238} \mathrm{U} /{ }^{232} \mathrm{Th}\right)$ plot. Aluminosilicate

458 detritus rarely has ${ }^{238}$ U excesses (e.g. Szabo and Rosholt, 1982; Porcelli and Swarzenski, 2003).

459 This is because rocks generally weather under oxidizing conditions present at and near the

460 Earth's surface, where U is soluble and will be leached from rocks (e.g. Porcelli and Swarzenski,

$4612003)$.

462

4635.2 Approaches and limitations for determining ${ }^{230}$ Th ages for Samail carbonates

$464 \quad 5.2 .1^{230}$ Th dating of terrestrial carbonates

465

${ }^{230}$ Th dating of carbonates measures the ingrowth of ${ }^{230} \mathrm{Th}$ from the decay of ${ }^{238} \mathrm{U}$ and

$466{ }^{234} \mathrm{U}$ incorporated into the carbonate matrix during formation. Since Th is generally highly

467 insoluble relative to $\mathrm{U}$, carbonate that forms (either through inorganic precipitation or biological

468 processes) from marine and terrestrial waters generally contains relatively high $\mathrm{U}$ concentrations

469 and low Th concentrations. This creates disequilibria in the ${ }^{238} \mathrm{U}$ decay chain, which gradually

470 returns to equilibrium as ${ }^{238} \mathrm{U}$ (half-life: $\sim 4.47 \times 10^{9}$ years) and ${ }^{234} \mathrm{U}$ (half-life: $\sim 2.45 \times 10^{5}$ years)

471 decay to ${ }^{230}$ Th (half-life: $\sim 7.56 \times 10^{9}$ years). 
${ }^{230}$ Th dating of carbonates relies on two primary assumptions: (1.) there was no initial

$473{ }^{230} \mathrm{Th}$ incorporated when the carbonate formed and (2.) there has been no loss or addition of $\mathrm{U}$

474 and Th since carbonate formation. In practice, these two assumptions are valid only for un-

475 recrystallized, pure carbonates such as some corals and speleothems (e.g. Edwards et al., 2003;

476 Scholz and Hoffmann, 2008). For many carbonates, these assumptions are not valid and

477 corrections must be employed in the dating technique. If initial ${ }^{230} \mathrm{Th}$ is present in a carbonate

478 sample, then it may be possible to correct for this initial ${ }^{230} \mathrm{Th}$ (e.g. Bischoff and Fitzpatrick,

479 1991; Luo and Ku, 1991; Kaufman, 1993; Edwards et al., 2003). Carbonates affected by open

480 system behavior after formation, such as recrystallized corals and lacustrine carbonate with

481 added hydrogenous $\mathrm{U}$ or Th, are challenging to date unless the open system behavior can be

482 estimated using models (e.g. Fontes et al., 1992; Thompson et al., 2003; Villemant and Feullet,

$483 \quad 2003$; Haase-Schramm et al., 2004).

$484 \quad$ Terrestrial carbonates are usually affected by the presence of initial ${ }^{230} \mathrm{Th}$ and, to a lesser 485 extent, by ${ }^{234} \mathrm{U}$ and ${ }^{238} \mathrm{U}$ contributed by detrital material (e.g. Bischoff and Fitzpatrick, 1991; Luo 486 and $\mathrm{Ku}, 1991$; Kaufman, 1993). Detritus incorporated into terrestrial carbonates is often fine487 grained and intergrown with the carbonate, making physical separation very difficult (e.g. Ku 488 and Liang, 1984; Bischoff and Fitzpatrick, 1991; Luo and Ku, 1991). Various approaches have 489 been attempted over the years to account for detrital ${ }^{230} \mathrm{Th},{ }^{234} \mathrm{U}$, and ${ }^{238} \mathrm{U}$ in terrestrial carbonates 490 to enable dating of these carbonates. Early studies (e.g. Harmon et al., 1977) attempted to 491 separate the carbonate material from the admixed detritus by employing light acid leaches. 492 However, numerous subsequent studies (e.g. Schwarcz and Latham, 1989; Przybylowicz et al., 493 1991; Bischoff and Fitzpatrick, 1991; Luo and Ku, 1991) have demonstrated that fractionation of $494 \mathrm{U}$ and Th concentrations and shifts in isotopic ratios can occur during incomplete acid leaching. 
Fractionation of $\mathrm{U}$ and Th concentrations and isotopes was also observed during partial dissolution experiments conducted on our Samail carbonate samples (see Supplementary Information). A number of studies have investigated and employed pseudoisochron methods for determining the composition of incorporated detritus (e.g. Osmond et al., 1970; Schwarcz and Latham, 1989; Przybylowicz et al., 1991; Bischoff and Fitzpatrick, 1991; Luo and Ku, 1991). However, pseudoisochron methods are limited by the requirement of a set of coeval samples with variable detritus/carbonate ratios and thus are not suitable for dating the Samail carbonates analyzed in this study since the Samail travertines and Mg-rich carbonate veins are known to have a range of ages based on previous ${ }^{14} \mathrm{C}$ dating (Mervine et al., 2014).

For most terrestrial carbonates, employing total sample dissolutions with corrections for detrital ${ }^{230} \mathrm{Th}$ (and sometimes also ${ }^{234} \mathrm{U}$ and ${ }^{238} \mathrm{U}$ ) is the most robust way to determine ${ }^{230} \mathrm{Th}$ ages for the carbonates (e.g. Ludwig and Titterington, 1994; Edwards et al., 2003; Ludwig et al., 2011). The simplest and most commonly employed detrital correction approach uses ${ }^{232} \mathrm{Th}$ as an indicator isotope for the ${ }^{230} \mathrm{Th}$ correction. In this method, all ${ }^{232} \mathrm{Th}$ is assumed to originate from detritus, and the measured $\left({ }^{232} \mathrm{Th} /{ }^{238} \mathrm{U}\right)$ of the terrestrial carbonate is used to weight the ${ }^{230} \mathrm{Th}$ correction. The $\left({ }^{230} \mathrm{Th} /{ }^{232} \mathrm{Th}\right)$ composition of the detrital material is rarely known explicitly and is generally the largest source of uncertainty in corrected ${ }^{230}$ Th ages. Often, a Bulk Silicate Earth (BSE) value for $\left({ }^{230} \mathrm{Th} /{ }^{232} \mathrm{Th}\right)$ of 0.814 (calculated assuming equilibrium with $\left({ }^{238} \mathrm{U} /{ }^{232} \mathrm{Th}\right)=$ $\left.\left({ }^{230} \mathrm{Th} /{ }^{232} \mathrm{Th}\right)\right)$ is assumed for the detritus (e.g. Ludwig and Titterington, 1994; Ludwig et al., 2011). Although the required assumptions are not necessarily geologically sound, assuming a BSE $\left({ }^{230} \mathrm{Th} /{ }^{232} \mathrm{Th}\right)$ value works for older carbonates with high $\mathrm{U}$ and low ${ }^{232} \mathrm{Th}$ contents because the resulting correction is relatively insignificant, such that the assumed $\left({ }^{230} \mathrm{Th} /{ }^{232} \mathrm{Th}\right)$ value has a small effect on the calculated age (e.g. Bischoff and Fitzpatrick, 1991; Kaufman, 1993; Ludwig 

522 ages.

and Titterington, 1994). However, for young carbonates and for carbonates with relatively low $\mathrm{U}$ concentrations and high ${ }^{232} \mathrm{Th}$ concentrations (such as the Samail carbonates), the assumed $\left({ }^{232} \mathrm{Th} /{ }^{230} \mathrm{Th}\right)$ value for the detrital material has a large effect on the calculated age, and therefore the $\left({ }^{232} \mathrm{Th} /{ }^{230} \mathrm{Th}\right)$ value must be known explicitly in order to reliably determine corrected ${ }^{230} \mathrm{Th}$

We have employed total dissolutions with corrections for initial ${ }^{230} \mathrm{Th}$ in an attempt to determine ${ }^{230} \mathrm{Th}$ ages for Samail carbonates. We have not employed corrections for detrital ${ }^{234} \mathrm{U}$ and ${ }^{238} \mathrm{U}$ because the initial ${ }^{230} \mathrm{Th}$ correction has the largest influence on the age corrections.. Because Samail carbonate ${ }^{230} \mathrm{Th}$ ages are so sensitive to initial ${ }^{230} \mathrm{Th}$ corrections and because there is not an obvious single detrital $\left({ }^{230} \mathrm{Th} /{ }^{232} \mathrm{Th}\right)$ value to use for the corrections, a sensitivity analysis approach has been employed to evaluate the influence of detrital ${ }^{230} \mathrm{Th}$ on the calculated ${ }^{230}$ Th ages of the Samail carbonates.

To evaluate a reasonable range of detrital $\left({ }^{230} \mathrm{Th} /{ }^{232} \mathrm{Th}\right)$ values to use for the initial ${ }^{230} \mathrm{Th}$ correction for the Samail carbonate ${ }^{230}$ Th ages, we compiled 300 literature values for $\left({ }^{230} \mathrm{Th} /{ }^{232} \mathrm{Th}\right)$ measured in various types (soil, saprolite, alluvium, colluvium, till, and volcanic ash) of aluminosilicate detritus (see Supplementary Information). These data were compiled from Rosholt et al. (1966), Hansen and Stout (1968), Hansen (1970), Rosholt et al. (1985), Mathieu et al. (1995), Dequincey et al. (2002), Krishnaswami et al. (2004), Dosseto et al. (2008), Pelt et al. (2008), and Ma et al. (2010). This compilation has $\left({ }^{230} \mathrm{Th} /{ }^{232} \mathrm{Th}\right)$ values ranging from 0.02 to 4.61 (average: $0.77,2 \sigma$ standard deviation: 0.50 ). While the average $\left({ }^{230} \mathrm{Th} /{ }^{232} \mathrm{Th}\right.$ ) of the compiled detritus values is fairly close to the equilibrium BSE value of 0.814, aluminosilicate detritus clearly has a wide range of $\left({ }^{230} \mathrm{Th} /{ }^{232} \mathrm{Th}\right)$ values. Our results show that the $\left({ }^{230} \mathrm{Th} /{ }^{232} \mathrm{Th}\right)$ value of the detritus incorporated into the Samail carbonates may be higher than the equilibrium 
541

542

543

544

545

546

547

548

549

550

551

552

553

554

555

556

557

558

559

560

561

562

563

BSE value. The recently formed travertine precipitates OM09-8COPS-MS and OM09-10COPSMS have $\left({ }^{230} \mathrm{Th} /{ }^{232} \mathrm{Th}\right)$ values of 1.376 and 1.416 , respectively. These two precipitates are essentially zero age with respect to the half-life of ${ }^{230} \mathrm{Th}$ (based on ${ }^{14} \mathrm{C}$ measurements and field relations, see Mervine et al., 2014). While the $\left({ }^{230} \mathrm{Th} /{ }^{232} \mathrm{Th}\right)$ value of detritus incorporated in Samail carbonates is clearly spatially and temporally variable, it is important to note that the $\left({ }^{230} \mathrm{Th} /{ }^{232} \mathrm{Th}\right)$ values measured in the recently-formed precipitates (likely formed a matter of days or weeks before collection and therefore should have minimal ingrown ${ }^{230} \mathrm{Th}$ ) are similar and provide a possible correction value to use for older travertine samples. $\left({ }^{230} \mathrm{Th} /{ }^{232} \mathrm{Th}\right)$ values measured in wadi sediments also provide possible values to use for initial ${ }^{230} \mathrm{Th}$ corrections for the Samail carbonate ${ }^{230} \mathrm{Th}$ ages. One of the wadi sediments has a $\left({ }^{230} \mathrm{Th} /{ }^{232} \mathrm{Th}\right)$ value of 2.093 , somewhat similar to the values measured in the two recently-formed travertine precipitates.

However, wadi sediment OM09-8S-MS, which consists primarily of serpentine, has a higher $\left({ }^{230} \mathrm{Th} /{ }^{232} \mathrm{Th}\right)$ value of 5.215 . Clearly, there is significant variability in the measured $\left({ }^{230} \mathrm{Th} /{ }^{232} \mathrm{Th}\right)$ values of detritus that may have been incorporated into the Samail carbonates.

\subsection{2 ${ }^{230}$ Th dating of Samail travertines}

Uncorrected ${ }^{230} \mathrm{Th}$ ages for Samail travertines are presented in Table 3. For all travertines analyzed, the uncorrected ${ }^{230} \mathrm{Th}$ ages are significantly older than the corresponding ${ }^{14} \mathrm{C}$ ages (Mervine et al., 2014). The low U concentrations and relatively high U/Th ratios found in the Samail travertines makes obtaining detritus corrected ${ }^{230} \mathrm{Th}$ ages highly challenging. The travertines contain significant detrital $\mathrm{Th}$, and the values of corrected ${ }^{230} \mathrm{Th}$ ages are thus highly sensitive to the selected value of initial $\left({ }^{230} \mathrm{Th} /{ }^{232} \mathrm{Th}\right)$ employed in the corrections. Varying the assumed initial $\left({ }^{230} \mathrm{Th} /{ }^{232} \mathrm{Th}\right)$ over the range observed in wadi sediments, BSE, and our 
564 compilation of aluminosilicate detritus (see Supplementary Information) changes the corrected

565 travertine ${ }^{230}$ Th ages by tens of thousands of years. As an example, Figure 8 displays the effect

566 of the selected initial $\left({ }^{230} \mathrm{Th} /{ }^{232} \mathrm{Th}\right)$ value on the corrected ${ }^{230} \mathrm{Th}$ age for travertine terraces sample

567 OM09-106C-MS-A. Similar figures for all travertine samples are presented in the Supplementary

568 Information.

569 For all travertine samples, geologically plausible detrital $\left({ }^{230} \mathrm{Th} /{ }^{232} \mathrm{Th}\right)$ values bring the 570 corrected ${ }^{230} \mathrm{Th}$ ages into concordance with the ${ }^{14} \mathrm{C}$ ages presented in Mervine et al. (2014). For

571 example, an assumed detrital $\left({ }^{230} \mathrm{Th} /{ }^{232} \mathrm{Th}\right)$ value of $\sim 1.7$ produces a corrected ${ }^{230} \mathrm{Th}$ or sample

572 OM09-106C-MS-A that is concordant with the ${ }^{14} \mathrm{C}$ age of $30,023 \pm 235 \mathrm{yr}$ BP reported in

573 Mervine et al. (2014). Unfortunately, no single detrital $\left({ }^{230} \mathrm{Th} /{ }^{232} \mathrm{Th}\right)$ value consistently corrects

574 the travertine ${ }^{230} \mathrm{Th}$ ages to the corresponding ${ }^{14} \mathrm{C}$ ages. The different $\left({ }^{230} \mathrm{Th} /{ }^{232} \mathrm{Th}\right)$ corrections

575 required for each travertine are likely a result of the observed heterogeneous nature of the

576 detritus. Therefore, although geologically plausible $\left({ }^{230} \mathrm{Th} /{ }^{232} \mathrm{Th}\right)$ values can be selected for each

577 travertine to bring the corrected ${ }^{230}$ Th age into concordance with the ${ }^{14} \mathrm{C}$ age, the lack of a

578 uniform $\left({ }^{230} \mathrm{Th} /{ }^{232} \mathrm{Th}\right)$ correction value precludes obtaining precise ages for Samail travertines

$579 \quad$ using ${ }^{230}$ Th dating alone.

580

$581 \quad 5.2 .3^{230}$ Th dating of Samail Mg-rich carbonate veins

582 Uncorrected ${ }^{230} \mathrm{Th}$ ages for Mg-rich carbonate vein samples are presented in Table 3.

583 Four out of the five Mg-rich carbonate outcrop vein samples have uncorrected ${ }^{230} \mathrm{Th}$ ages that are

584 younger than the corresponding ${ }^{14} \mathrm{C}$ ages (Mervine et al., 2014). The exception is sample OM10-

585 84C-MG, which has a ${ }^{230} \mathrm{Th}$ age older than its ${ }^{14} \mathrm{C}$ age. While not particularly high, the $\sim 2 \mathrm{ppb}$

586 Th concentration of sample OM10-84C-MG is significant relative to its low U concentration of 
$587 \sim 1 \mathrm{ppb}$. Therefore, sample OM10-84C-MG likely contained significant initial ${ }^{230} \mathrm{Th}$ relative to its 588 U concentration. Furthermore, the Th/U ratio (1.995) of OM10-84C-MG is significantly higher 589 than the other carbonate outcrop veins, which have $\mathrm{Th} / \mathrm{U}$ ratios of $\sim 0.2$ to $\sim 0.3$.

$590 \quad$ Since the uncorrected ${ }^{230} \mathrm{Th}$ ages of the Mg-rich carbonate outcrop veins are generally 591 younger than the corresponding ${ }^{14} \mathrm{C}$ ages, corrections for initial ${ }^{230} \mathrm{Th}$ from detritus cannot be 592 employed to make the two sets of ages concordant since initial ${ }^{230}$ Th corrections would make the $593{ }^{230} \mathrm{Th}$ ages even younger. Figure 9 illustrates the effect of a range of initial ${ }^{230} \mathrm{Th}$ corrections for 594 Mg-rich carbonate outcrop vein OM10-13C-MG. Similar figures for all of the Mg-rich carbonate 595 outcrop vein samples are presented in the Supplementary Information. Possibly, a detrital 596 correction employing an unusual detritus with ${ }^{238} \mathrm{U}$ enrichment, such as a highly altered 597 peridotite, could be employed to make the ${ }^{230} \mathrm{Th}$ ages older. There are two possible end member explanations for the discrepancies between the ${ }^{230} \mathrm{Th}$ 599 and ${ }^{14} \mathrm{C}$ ages for the $\mathrm{Mg}$-rich carbonate outcrop vein samples. The first explanation is that the $600{ }^{230} \mathrm{Th}$ ages are correct but the ${ }^{14} \mathrm{C}$ ages are too old because of the incorporation of recycled, ${ }^{14} \mathrm{C}$ 601 dead carbon. The second explanation is that the ${ }^{230}$ Th ages are too young because of ${ }^{238} \mathrm{U}$ 602 addition from U-bearing fluids. Essentially, hexavalent U, which is highly soluble, is being 603 carried down from the surface by the oxidized Type I waters; this U is subsequently deposited as 604 tetravalent $U$ by the Type II reducing serpentinization fluids. We also note that if the carbonate 605 outcrop veins were modified by $\mathrm{U}$ addition from fluid, then their ${ }^{14} \mathrm{C}$ ages may have also been 606 partially or fully re-set. Therefore, because of the possible effects of incorporated old carbon 607 with no ${ }^{14} \mathrm{C}$ and/or open system addition of young carbon with high ${ }^{14} \mathrm{C}$, the ${ }^{14} \mathrm{C}$ ages of altered $608 \mathrm{Mg}$-rich carbonate veins should be interpreted with caution. The ${ }^{14} \mathrm{C}$ ages could be affected by 609 both types of end member open system behavior, including multiple generations of open system 
610 behavior. The uncorrected ${ }^{230} \mathrm{Th}$ ages for the Mg-rich carbonate roadcut vein samples are 611 significantly older than the uncorrected ${ }^{230} \mathrm{Th}$ ages for the Mg-rich carbonate outcrop vein 612 samples. The roadcut vein samples have $\left({ }^{230} \mathrm{Th} /{ }^{238} \mathrm{U}\right)$ values approaching equilibrium. Mg-rich 613 carbonate roadcut vein samples OM09-35C-MS, OM09-55C-MS, and OM09-57C-MS have $614\left({ }^{230} \mathrm{Th} /{ }^{238} \mathrm{U}\right)$ values of $1.068,0.956$, and 0.984 , respectively. Furthermore, Mg-rich roadcut vein 615 samples OM09-57C-MS, and OM09-58C-MS have near-equilibrium $\left({ }^{234} \mathrm{U} /{ }^{238} \mathrm{U}\right)$ values of 1.010 , 616 and 0.998 , respectively. These four $\mathrm{Mg}$-rich carbonate roadcut vein samples are ${ }^{14} \mathrm{C}$ dead,

617 suggesting that their ages are $>50,000 \mathrm{yr}$ BP (Mervine et al., 2014). Thus, the older ${ }^{230}$ Th ages 618 suggested by the near-equilibrium $\left({ }^{230} \mathrm{Th} /{ }^{238} \mathrm{U}\right)$ and $\left({ }^{234} \mathrm{U} /{ }^{238} \mathrm{U}\right)$ values are consistent with the ${ }^{14} \mathrm{C}$ 619 data. As shown in Figure 10, applying a wide range of $\left({ }^{230} \mathrm{Th} /{ }^{232} \mathrm{Th}\right)$ detrital values for an initial $620{ }^{230}$ Th correction does not affect the ${ }^{230} \mathrm{Th}$ age of sample OM09-57C-MS significantly.

621 Unfortunately, Th isotopes could not be measured in Sample OM09-58C-MS due to its low Th 622 concentration. Given the long half-life of ${ }^{234} U\left(t_{1 / 2}=245.3 \mathrm{kyr}\right)$, the near-equilibrium $\left({ }^{234} \mathrm{U} /{ }^{238} \mathrm{U}\right)$ 623 values for these two veins suggest that these samples are several hundred thousand years old. An 624 alternate explanation would be that these samples started out with $\left({ }^{234} \mathrm{U} /{ }^{238} \mathrm{U}\right)$ in equilibrium. 625 However, we consider this an unlikely initial condition given: (1.) the extent of $\left({ }^{234} \mathrm{U} /{ }^{238} \mathrm{U}\right)$ 626 disequilibria observed in the other Mg-carbonate samples (Figure 6); (2.) that most crustal waters 627 (seemingly including those forming these veins, see Figure 6) are enriched in ${ }^{234} \mathrm{U}$ relative to $628{ }^{238} \mathrm{U}$, because of well-documented alpha recoil and lattice damage effects (Porcelli and 629 Swarzenski, 2003); and (3.) these inferred old ages are consistent with other isotopic 630 characteristics which also indicate that they are old, namely equilibrium $\left({ }^{230} \mathrm{Th} /{ }^{238} \mathrm{U}\right)$ and ${ }^{14} \mathrm{C}$ 631 dead radiocarbon measurements. 
6331.542 , which is a value that cannot be reached through closed-system ${ }^{238} \mathrm{U}$ decay and ${ }^{230} \mathrm{Th}$

634 ingrowth. Therefore, no ${ }^{230} \mathrm{Th}$ age can be determined for this sample. The high $\left({ }^{230} \mathrm{Th} /{ }^{238} \mathrm{U}\right)$ value 635 of this sample is likely explained by high detrital ${ }^{230} \mathrm{Th}$ since it has a very high Th/U ratio of 5.6.

\subsection{Implications for natural rates of carbonate formation in Samail peridotite}

The determination of precise ${ }^{230} \mathrm{Th}$ ages for Samail carbonatesis limited by large and

639 uncertain initial ${ }^{230}$ Th corrections. Nevertheless, the $\mathrm{U}$ and Th systematics and the age limits

640 from the ${ }^{230} \mathrm{Th}$ dating attempts permit further refinement of previous estimates of natural rates of

641 carbon sequestration in Samail carbonates (Kelemen and Matter, 2008; Kelemen et al., 2011;

642 Mervine et al., 2014).

The fact that geologically reasonable initial ${ }^{230} \mathrm{Th}$ corrections bring ${ }^{230} \mathrm{Th}$ and ${ }^{14} \mathrm{C}$ ages for

644 travertines into concordance further supports prior inferences that ${ }^{14} \mathrm{C}$ dating of travertines is 645 generally reliable and these ages can be interpreted as formation ages. This places additional

646 confidence on the estimates, based on ${ }^{14} \mathrm{C}$ dating, that travertine precipitation rates are $\sim 0.1$ to

$647 \sim 0.3 \mathrm{~mm} / \mathrm{yr}$ and that travertines in the Samail Ophiolite are sequestering a maximum of $\sim 1$ to 3

$648 \times 10^{6} \mathrm{~kg} \mathrm{CO}_{2} / \mathrm{yr}$ (Mervine et al., 2014).

$649 \mathrm{U}$ and Th systematics and ${ }^{230} \mathrm{Th}$ ages for the Mg-rich carbonate vein samples also provide 650 further evidence that there are multiple generations of $\mathrm{Mg}$-rich carbonate veins in the peridotite 651 subsurface. The fact that the $\mathrm{Mg}$-rich carbonate outcrop veins have ${ }^{230} \mathrm{Th}$ ages younger than the 652 corresponding ${ }^{14} \mathrm{C}$ ages suggests that these carbonate veins may have been altered by U-bearing 653 fluids within the last 375,000 years. The lack of concordance between ${ }^{230} \mathrm{Th}$ and ${ }^{14} \mathrm{C}$ ages for the 654 Mg-rich carbonate outcrop veins also suggests that these carbonate veins may have been affected 
655 by open system behavior, most likely dissolution and re-precipitation of previous generations of

656 carbonate veins. Such open system behavior may have perturbed both the ${ }^{14} \mathrm{C}$ and ${ }^{230} \mathrm{Th}$ ages for 657 Mg-rich carbonate veins.

658 The near-equilibrium $\left({ }^{230} \mathrm{Th} /{ }^{238} \mathrm{U}\right)$ and $\left({ }^{234} \mathrm{U} /{ }^{238} \mathrm{U}\right)$ values measured in the less weathered, $659{ }^{14} \mathrm{C}$ dead, $\mathrm{Mg}$-rich carbonate roadcut veins suggest that, at certain exposures such as Fanja

660 Roadcut, there may be much older (possibly older than 1 million years, based on the equilibrium $661{ }^{234} \mathrm{U} /{ }^{238} \mathrm{U}$ values) generations of Mg-rich carbonate veins preserved at these localities. Therefore, 662 carbonate vein formation in the peridotite layer of the Samail Ophiolite has likely been ongoing 663 for at least the past 50,000 years and possibly for a much longer time. Hence, sensitivity analysis, 664 such as that presented in Mervine et al. (2014), that considers the impact of multiple generations 665 of carbonate vein formation on the estimated rate of $\mathrm{CO}_{2}$ sequestration in subsurface carbonate 666 veins is essential since there is no single "average" carbonate vein age. The sensitivity analysis 667 presented in Mervine et al. (2014) indicates that ongoing Mg-rich carbonate vein formation in 668 the peridotite layer of the Samail Ophiolite sequesters on the order of $10^{7} \mathrm{~kg}$ of $\mathrm{CO}_{2}$ per year, 669 consistent with less well-constrained, previous estimates (Kelemen and Matter 2008; Kelemen et 670 al. 2011).

671

\subsection{Implications for U-Th disequilibria dating of terrestrial Quaternary carbonates}

673

The results of this study indicate that U-Th disequilibria dating of Quaternary carbonate

674 alteration minerals formed in ophiolite peridotites is highly challenging, due to low U

675 concentrations, high $\mathrm{Th} / \mathrm{U}$ ratios, and the open system nature of some of the carbonates. This

676 study concurs with previous investigations (e.g Schwarcz and Latham, 1989; Przybylowicz et al.,

677 1991; Kaufman, 1993) that partial dissolution approaches are not recommended for U-Th 
678 disequilibria dating of terrestrial carbonates, due to fractionation of $U$ and $T h$ concentrations and

679 isotopic values. Unfortunately, U-Th disequilibria dating approaches employing total

680 dissolutions with detrital corrections (e.g. Kaufman, 1993; Ludwig et al., 2003) were also

681 challenging to implement. The travertine samples analyzed in this study contained high amounts

682 of detritus, which appears to be heterogeneous in nature with no single $\left({ }^{230} \mathrm{Th} /{ }^{232} \mathrm{Th}\right)$ correction

683 value that can be employed to determine reliable ages that are comparable with previously

684 obtained ${ }^{14} \mathrm{C}$ ages. The very low $\mathrm{U}$ concentrations of the subsurface carbonate vein samples

685 required the dissolution of large amounts of carbonate material. In addition, although the

686 subsurface carbonate vein samples contained significantly less detritus than the travertines, the

687 very low $U$ concentrations of these samples means that the age calculations remain highly

688 sensitive to detrital corrections. Furthermore, combined analysis of U-Th disequilibria

689 systematics and ${ }^{14} \mathrm{C}$ dating indicates that some of the subsurface carbonate veins have been

690 affected by open system behavior. In this case, neither the U-Th disequilibria nor the ${ }^{14} \mathrm{C}$ ages

691 can be considered reliable. However, investigation of U-Th systematics was a useful tool for

692 identifying this open system behavior, even though U-Th disequilibria ages could not be

693 determined.

694 The determination of precise U-Th disequilibria ages for carbonate alteration minerals

695 formed in peridotites with low $\mathrm{U}$ concentrations is likely to remain highly challenging. Thus, 696 other dating techniques, such as (U-Th)-He dating of magnetite, an alteration product formed in 697 association with serpentine minerals and also carbonate (e.g. Hernandez Goldstein et al., 2014), 698 may have to be explored to better understand timescales of natural peridotite alteration.

699 However, U-Th disequilibria dating techniques should remain useful for dating carbonate 
700 alteration products in seafloor peridotites since these carbonates commonly have higher $\mathrm{U}$

701 concentrations due to U contributions from seawater (e.g. Ludwig et al., 2011).

$702 \quad \mathrm{U}-\mathrm{Th}$ disequilibria dating techniques, as well as $\mathrm{U}-\mathrm{Pb}$ dating techniques, could also

703 potentially prove useful for dating carbonate alteration products that form in other types of

704 igneous rocks that have higher U concentrations. For example, these techniques could potentially

705 be used to determine ages of kimberlite carbonates. Although kimberlites, like peridotites, are

706 ultramafic rocks comprised largely of olivine (as a primary mineral and as macrocrysts) and

707 pyroxene (as xenocrysts), they have significantly higher U concentrations (ppm level) than

708 peridotites since they are formed through low degrees of mantle melting (e.g. Mitchell, 1986).

709 Potentially, the U-Th disequilibria and U-Pb dating techniques could help kimberlite geologists

710 better understand which carbonates are primary (i.e. magmatic) and which are secondary (i.e.

711 formed through alteration processes). However, some work will be required to better understand

712 the distribution of $U$ and $T h$ in kimberlite minerals. For example, $U$ will most likely be

713 concentrated in minerals such as apatite and perovskite (e.g. Mitchell, 1986), and magmatic

714 carbonates could potentially contain significant Th. Although challenges remain and these must

715 be properly understood and accounted for, U-Th disequilibria dating nevertheless remains an

716 important tool to consider for the dating of several types of terrestrial carbonates, including some

717 types of carbonate alteration minerals.

718

719 6. Conclusions

720 This study highlights the difficulties of using ${ }^{238} \mathrm{U}_{-}{ }^{234} \mathrm{U}_{-}{ }^{230} \mathrm{Th}$ disequilibria measurements to

721 determine ages for carbonate alteration minerals formed in peridotite. Our efforts to use ${ }^{238} \mathrm{U}-$ 
$722{ }^{234} \mathrm{U}_{-}{ }^{230} \mathrm{Th}$ measurements to date both travertines and $\mathrm{Mg}$-rich carbonate veins in the peridotite 723 layer of the Samail Ophiolite show:

724

(1.) Samail carbonates have extremely low $U$ and Th concentrations, which reflect the low $\mathrm{U}$ and Th concentrations found in Samail peridotites and associated groundwaters. The higher $\mathrm{U}$ and Th concentrations observed in surface travertine terraces relative to subsurface carbonate veins likely result from the higher amounts of aluminosilicate detritus incorporated into these surface samples. The low $\mathrm{U}$ concentrations and relatively high $\mathrm{Th} / \mathrm{U}$ ratios found in Samail travertines make obtaining ${ }^{230}$ Th ages highly challenging.

(2.) The $\left({ }^{238} \mathrm{U} /{ }^{232} \mathrm{Th}\right)$ versus $\left({ }^{230} \mathrm{Th} /{ }^{232} \mathrm{Th}\right)$ pseudoisochron method cannot be rigorously used to date the Samail carbonate alteration minerals. This method requires coeval samples, and the Samail travertines and Mg-rich carbonate veins have a large range of ${ }^{14} \mathrm{C}$ ages (Mervine et al., 2014) relative to the half-life of ${ }^{230} \mathrm{Th}$. The travertine ages in particular can vary by thousands of years over short distances ( $\mathrm{mm}$ to $\mathrm{cm}$ scale).

(3.) Partial dissolution experiments to separate the fine-grained, inter-grown aluminosilicate detritus from the carbonate show that even light acid leaching significantly perturbs U/Th and $\left({ }^{230} \mathrm{Th} /{ }^{232} \mathrm{Th}\right)$ of the dissolved carbonates. These isotopic and elemental perturbations are from partial leaching of the fine-grained silicates. Because this leached out silicate contribution cannot be explicitly quantified, partial dissolution is not a viable method for dating the carbonate. 
(4.) For the travertines, because of the issues outlined in conclusions 1,2 and 3 above, the most viable method for obtaining reliable ${ }^{238} \mathrm{U}_{-}{ }^{234} \mathrm{U}_{-}{ }^{230} \mathrm{Th}$ ages is total dissolution and correcting for the ${ }^{230} \mathrm{Th}$ contributed by the detritus. Because these travertines contain significant initial ${ }^{230} \mathrm{Th}$ from detritus, the values of the ages obtained through correction for ${ }^{230} \mathrm{Th}$ from detritus are highly sensitive to the selected value of initial $\left({ }^{230} \mathrm{Th} /{ }^{232} \mathrm{Th}\right)$ used in the correction. For all travertine samples, varying the initial $\left({ }^{230} \mathrm{Th} /{ }^{232} \mathrm{Th}\right)$ used in the correction changes the ages of the travertines by tens of thousands of years. However, geologically plausible initial $\left({ }^{230} \mathrm{Th} /{ }^{232} \mathrm{Th}\right)$ values correct the travertine ${ }^{230} \mathrm{Th}$ ages to the corresponding ${ }^{14} \mathrm{C}$ ages (Mervine et al., 2014). This age concordance suggests that the travertines are closed systems, adding a level of credence to the reliability of the ${ }^{14} \mathrm{C}$ ages (Mervine et al., 2014) and even the Useries dates (albeit with large uncertainties) obtained in this study.

(5.) Most Mg-rich carbonate veins from outcrops on the natural peridotite weathering surface have uncorrected ${ }^{230} \mathrm{Th}$ ages that are younger than the corresponding ${ }^{14} \mathrm{C}$ ages. The lack of concordance between ${ }^{230} \mathrm{Th}$ and ${ }^{14} \mathrm{C}$ ages for the $\mathrm{Mg}$-rich carbonate outcrop veins indicates that these carbonate veins have been affected by open system behavior, most likely dissolution and re-precipitation of previous generations of carbonate veins and old carbon. Alternatively, the continuous addition of ${ }^{238} \mathrm{U}$ from fluids would make the ${ }^{230} \mathrm{Th}$ ages too young. If the carbonate outcrop veins were 
fully re-set and thus the ${ }^{14} \mathrm{C}$ ages of altered $\mathrm{Mg}$-rich carbonate veins should be interpreted with caution.

(6.) Some ${ }^{14} \mathrm{C}$ dead, Mg-rich carbonate veins from roadcuts have $\left({ }^{230} \mathrm{Th} /{ }^{238} \mathrm{U}\right)$ and $\left({ }^{234} \mathrm{U} /{ }^{238} \mathrm{U}\right)$ values approaching equilibrium and are likely $>>375,000$ years in age. The variable (young and old) ages for the Mg-rich carbonate veins support the conclusions of ${ }^{14} \mathrm{C}$ dating (Clark and Fontes, 1990; Clark et al., 1992; Kelemen and Samail Ophiolite.

(7.) Overall, this study has shown that using ${ }^{238} \mathrm{U}_{-}{ }^{234} \mathrm{U}_{-}{ }^{230}$ Th disequilibria measurements to determine ages for carbonate alteration minerals formed in peridotite is challenging due to the generally low $\mathrm{U}$ concentrations and high $\mathrm{Th} / \mathrm{U}$ ratios of the carbonates. In particular, further development is required to better account for the isotopic signature of admixed aluminosilicate detritus. Nevertheless, this study has shown that investigation of U-Th systematics is a useful tool for identifying open system behavior in some carbonate alteration minerals, even when precise U-Th disequilibria ages cannot be determined. In addition, U-Th disequilibria dating techniques remain useful for dating carbonate alteration products in seafloor peridotites since these carbonates commonly have higher $\mathrm{U}$ concentrations due to $\mathrm{U}$ contributions from seawater (e.g. Ludwig et al., 2011). U-Th disequilibria dating techniques could also 
potentially prove useful for dating carbonate alteration products that form in other types of igneous rocks that have higher U concentrations, such as basalts and kimberlites.

795

796

\section{Acknowledgments}

Ali Al-Rajhi, Ministry of Commerce and Industry, Sultanate of Oman, and Sobhi Nasir, Sultan Qaboos University, are thanked for logistical support during field seasons. The Oman field teams are thanked for assistance with fieldwork and for scientific discussions. Jerzy Blusztajn is thanked for mentorship and assistance in the laboratory, and Vera Pavel is thanked for assistance with MATLAB programming. Jürg Matter is thanked for providing the water samples. This research was funded by National Science Foundation grants EAR-1049281 and EAR-1049905, the Deep Ocean Exploration Institute at Woods Hole Oceanographic Institution,

804 the Academic Programs Office at Woods Hole Oceanographic Institution, the Mellon 805 Foundation, a Research Initiative in Science and Engineering Grant from Columbia University to Peter Kelemen and Jürg Matter, and Peter Kelemen's Arthur D. Storke Chair at Columbia

807 University. Lucy McGee and an anonymous reviewer are thanked for comments which improved the paper. David Hilton is thanked for editorial handling.

\section{References}

811 Ball, L., Sims, K. W. W., Schwieters, J., 2008. Measurement of ${ }^{234} \mathrm{U} /{ }^{238} \mathrm{U}$ and ${ }^{230} \mathrm{Th} /{ }^{232} \mathrm{Th}$ in 812 volcanic rocks using the Neptune MC-ICP-MS. Journal of Analytical Atomic Spectroscopy 23: 813 173-180.

814 
Barnes, I., O’Neil, J. R., 1969. The relationship between fluids in some fresh Alpine type ultramafics and possible modern serpentinization, Western United States. Geological Society of America Bulletin 80, 1947-1960.

Barnes, I., O’Neil, J. R., 1971. Calcium-magnesium carbonate solid solutions from Holocene conglomerate cements and travertines in the Coast Range of California. Geochimica et Cosmochimica Acta 35, 699-718.

Barnes, I., O’Neil, J. R., Trescases, J. J., 1978. Present-day serpentinization in New Caledonia, Oman, and Yugoslavia. Geochimica et Cosmochimica Acta 42,144-145.

Beinlich, A., Austrheim, H., 2012. In situ sequestration of atmospheric $\mathrm{CO}_{2}$ at low temperature and surface cracking of serpentinized peridotite in mine shafts. Chemical Geology 332-333, 32-44.

Bischoff, J. L., Fitzpatrick, J. A., 1991. U-series dating of impure carbonates: An isochron technique using total-sample dissolution. Geochimica et Cosmochimica Acta 55, 543-554.

Bodinier, J.-L., Godard, M., 2014. Orogenic, Ophiolitic, and Abyssal Peridotites. In: Holland, H., Turekian, K. (Eds.) Treatise on Geochemistry, $2^{\text {nd }}$ Edition, 103-166.

Brennecka, G. A., Borg, L. E., Hutcheon, I. D., Sharp, M. A., Anbar, A. D., 2010. Natural variations in uranium isotope ratios of uranium ore concentrates: Understanding the ${ }^{238} \mathrm{U} /{ }^{235} \mathrm{U}$ fractionation mechanism. Earth and Planetary Science Letters 291, 228-233.

Bruni, J., Canepa, M., Chiodini, G., Cioni, R., Cipolli, F., Longinelli, A., Marini, L., Ottonello, G., Zuccolini, M. V., 2002. Irreversible water-rock mass transfer accompanying the generation of the neutral, $\mathrm{Mg}_{-} \mathrm{HCO}_{3}$ and high-pH, Ca-OH spring waters of the Genova province, Italy. Applied Geochemistry 17, 455-474.

Charlou, J. L., Fouquet, Y., Bougalt, H., Donval, J. P., Etoubleau, J., Jean-Baptiste, P., Dapoigny, A., Apriou, P., Rona, P. A., 1998. Intense $\mathrm{CH}_{4}$ plumes generated by serpentinization of ultramafic rocks at the intersection of the $15^{\circ} 20^{\prime} \mathrm{N}$ fracture zone and the Mid-Atlantic Ridge. Geochimica et Cosmochimica Acta 62, 2323-2333.

Chavagnac, V., Ceuleneer, G., Monnin, C., Lansac, B., Hoareau, G., Boulart, C., 2013a. Mineralogical assemblages forming at hyperalkaline warm springs hosted on ultramafic rocks: A case study of Oman and Ligurian ophiolites. Geochemistry Geophysics Geosystems 14, 24742495 .

Chavagnac, V., Monnin, C., Ceuleneer, G., Boulart, C., Hoareau, G., 2013b. Characterization of hyperalkaline fluids produced by low-temperature serpentinization of mantle peridotites in the Oman and Ligurian ophiolites. Geochemistry Geophysics Geosystems 14, 2496-2522.

Cheng, H., Edwards, R. L., Hoff, J., Gallup, C. D., Richards, D. A., and Asmerom, Y., 2000. The half-lives of uranium-234 and thorium-230. Chemical Geology 169, 17-33. 
Cipolli, F., Gambardella, B., Marini, L., Otonello, G., Zuccolini, M. V., 2004. Geochemistry of

high-pH waters from serpentinites of the Gruppo di Voltri (Genova, Italy) and reaction path modeling of $\mathrm{CO}_{2}$ sequestration in serpentine aquifers. Applied Geochemistry 19, 787-802.

Clark, I. D., Fontes, J.-C., 1990. Paleoclimate reconstruction in northern Oman based on carbonate from hyperalkaline groundwaters. Quaternary Research 33, 320-336.

Clark, I. D., Fontes, J.-C., Fritz, P., 1992. Stable isotope disequilibria in travertine from high $\mathrm{pH}$ waters: Laboratory investigations and field observations from Oman. Geochimica et Cosmochimica Acta 56, 2041-2050.

Coleman R. G., 1977. Ophiolites. Springer-Verlag, New York.

Coleman, R. G., 1981. Tectonic setting for ophiolite obduction in Oman. Journal of Geophysical Research 86, 2497-2508.

Dequincey, O., Chabaux, F., Clauer, N., Sigmarsson, O., Liewig, N., Leprun, J.-C. 2002. Chemical mobilizations in laterites: Evidence from trace elements and ${ }^{238} \mathrm{U}_{-}{ }^{234} \mathrm{U}-{ }^{230} \mathrm{Th}$ disequilibria. Geochimica et Cosmochimica Acta 66, 1197-1210.

Dewandel, B., Lachassagne, P., Bakalowicz, M., Weng, P., Al-Malki, A., 2003. Evaluation of aquifer thickness by analyzing recession hydrographs: Application to the Oman ophiolite hardrock aquifer. Journal of Hydrology 274, 248-269.

Dewandel, B., Lachassagne, P., Qatan, A., 2004. Spatial measurements of stream baseflow, a relevant method for aquifer characterization and permeability evaluation: Application to a hard rock aquifer, Oman ophiolite. Hydrological Processes 18, 3391-3400.

Dewandel, B., Lachassagne, P., Boudier, F., Al-Hattali, S., Ladouche, B., Pinault, J.-L., Al-Suleimani, Z., 2005. A conceptual and hydrogeological model of ophiolite hard-rock aquifers in Oman based on a multiscale and multidisciplinary approach. Hydrogeology Journal 13, 708726.

Dooley, J. R., Tatsumoto, M., Rosholt, J. N., 1964. Radioactive disequilibrium studies of roll features, Shirley Basin, Wyoming. Economic Geology 59, 586-595.

Dooley, J. R., Granger, H. C., Rosholt, J. N., 1965. Uranium-234 fractionation in sandstone-type uranium deposits of the Ambrosia Lake District, New Mexico. Economic Geology 61, 13621382.

Dossetto, A., Turner, S.P., Chappell, J. 2008. The evolution of weathering profiles through time: New insights from uranium-series isotopes. Earth and Planetary Science Letters 274, 359-371.

Edwards, L. R., Chen, J. H., Wasserburg, G. J., 1986. ${ }^{238} \mathrm{U}_{-}{ }^{234} \mathrm{U}_{-}{ }^{230} \mathrm{Th}^{2}{ }^{232} \mathrm{Th}$ systematics and the precise measurement of time over the past 500,000 years. Earth and Planetary Science Letters 81, 175-192. 
Edwards, L. R., Gallup, C., Cheng, H., 2003. Uranium-series dating of marine and lacustrine carbonates. In: Bourdon, B., Henderson, G. M., Lundstrom, C. C., Turner, S. P. (Ed.), UraniumSeries Geochemistry. Reviews in Mineralogy and Geochemistry 52, 363-406.

Ferry, J. M., 1995. Fluid-flow during contact-metamorphism of ophicarbonate rocks in the Bergell-Aureole, Val-Malenco, Italian Alps. Journal of Petrology 36, 1039-1053.

Fleitmann, D., Burns, S. J., Neff, U., Mangini, A., Matter, A., 2003. Changing moisture sources over the last 350,000 years in northern Oman from fluid inclusion evidence in speleothems. Quaternary Research 60, 223-232.

Fontes, J.-C., Andrews, J. N., Causse, C., Gibert, E., 1992. A comparison of radiocarbon and U/Th ages on continental carbonates. Radiocarbon 34, 602-610.

Früh-Green, G. L., Kelley, D. S., Bernasconi, S. M., Karson, J. A., Ludwig, K. A., Butterfield, D. A., Boschi, C., Proskurowski, G. 2003. 30,000 years of hydrothermal activity at the Lost City vent field. Science 301, 495-498.

Gascoyne, M., 1992. Geochemistry of the actinides and their daughters. In: Ivanovich, M., Harmon, R. S. (Eds.), Uranium-series Disequilibria. Oxford, Claredon Press, pp. 34-61.

Ghaleb, B., Hillaire-Marcel, C., Causse, C., Gariepy, C., Vallieres, S., 1990. Fractionation and recycling of $U$ and $T h$ isotopes in a semi-arid endoreic depression of central Syria. Geochimica et Cosmochimica Acta 54, 1025-1035.

Glennie, K. W., Bouef, M. G. A., Hughes-Clarke, M. W., Moody-Stuart, M., Pilaar, W. F. H., Reinhart, B. M., 1973. Late Cretaceous nappes in the Oman mountains and their geological evolution. American Association of Petroleum Geologists Bulletin 57, 5-27.

Glennie, K. W., Bouef, M. G. A., Hughes-Clarke, M. W., Moody-Stuart, M., Pilaar, W. F. H., Reinhart, B. M. 1974. Geology of the Oman Mountains. Part I: Text. Part II: Tables and Illustrations. Part III: Enclosures. Verhandelingen van het Koniklijk Nederlands Geologisch Mijnbouwkundig Genootschap 31, pp. 423.

Govindaraju, K., 1994. Compilation of working values and sample description for 383 geostandards. Geostandards Newsletter 18 Special Issue, pp. 158.

Haase-Schramm, A., Goldstein, S. L., Stein, M., 2004. U-Th dating of Lake Lisan (late Pleistocene Dead Sea) aragonite and implications for glacial East Mediterranean climate change. Geochimica et Cosmochimica Acta 68, 985-1005.

Haggerty, J. A., 1991. Evidence from fluid seeps atop submarine seamounts in the Mariana forearc: clues for emplacement of the seamounts and their relationship to forearc tectonics. Marine Geology 102, 293-309. 
Hanhøj, K., Kelemen, P. B., Hassler, D., Godard, M., 2010. Composition and genesis of depleted mantle peridotites from the Wadi Tayin massif, Oman Ophiolite; Major and trace element geochemistry, and Os isotope and PGE systematics. Journal of Petrology 51, 201-227.

Hansen, R.O. and Stout, P.R. 1968. Isotopic distributions of uranium and thorium in soils. Soil Science 105, 44-50.

Hansen, R.O. 1970. Radioactivity of a California terrace soil. Soil Science 110, 31-36.

Harmon, S. R., Ford, D. C., Schwarcz, H. P., 1977. Interglacial chronology of the Rocky and Mackenzie Mountains based upon ${ }^{230} \mathrm{Th}-{ }^{234} \mathrm{U}$ dating of calcite speleothems. Canadian Journal of Earth Sciences 14, 2543-2552.

Harrison, A. L., Power, I. M., Dipple G. M., 2013. Accelerated carbonation of brucite in mine tailings for carbon sequestration. Environmental Science and Technology 47, 126-134.

Hellstrom, J., Pickering, R., 2015. Recent advances and future prospects of the U-Th and U-Pb chronometers applicable to archaeology. Journal of Archaeological Science 56: 32-40.

Hernandez Goldstein, E., Stockli, D., Ketcham, R., Seman, S., 2014. (U-Th)/He dating of magnetites in serpentinites (Abstract). Goldschmidt Geochemistry Conference, Sacramento, California.

Jaffey A. H., Flynn K. F., Glendenin L. E., Bentley W. C., Essling, A. M., 1971. Precision measurement of half-lives and specific activities of ${ }^{235} \mathrm{U}$ and ${ }^{238} \mathrm{U}$. Physical Review C 4, 18891906.

Kaufman, A., 1993. An evaluation of several methods for determining ${ }^{230} \mathrm{Th} / \mathrm{U}$ ages in impure carbonates. Geochimica et Cosmochimica Acta 57, 2303-2317.

Kelemen, P. B., Matter, J. M., 2008. In situ carbonation of peridotite for $\mathrm{CO}_{2}$ storage. Proceedings of the National Academy of Sciences 105, 17295-17300.

Kelemen, P. B., Matter, J. M., Streit, E. E., Rudge, J. F., Curry, W. B., Blusztajn, J., 2011. Rates and mechanisms of mineral carbonation in peridotite: Natural processes and recipes for enhanced, in situ $\mathrm{CO}_{2}$ capture and storage. Annual Review of Earth and Planetary Sciences 39, 545-576.

Kelley, D. S., Karson, J. A., Blackman, D. K., Früh-Green, G. L., Butterfield, D. A., Lilley, M. D., Olson, E. J., Schrenk, M. O., Roe, K. K., Lebon, G.T., Rivizzigo, P., 2001. An off-axis hydrothermal vent field near the Mid-Atlantic Ridge at 30 degrees N. Nature 412, 145-149.

Kelley, D. S., Karson, J. A., Früh-Green, G. L., Yoerger, D. R., Shank, T. M., Butterfield, D. A., Hayes, J. M., Schrenk, M. O., Olson, E. J., Proskurowski, G., Jakuba, M., Bradley, A., Larson, B., Ludwig, K., Glickson, D., Buckman, K., Bradley, A. S., Brazelton, W. J., Roe, K., Elend, M. J., Delacour, A., Bernasconi, S. M., Lilley, M. D., Baross, J. A., Summons, R. E., Sylvia, S. P., 
2005. A serpentinite-hosted ecosystem: The Lost City hydrothermal field. Science 307, 14281434.

Krishnaswami, S., Williams, G.A., Graustein, W.C., and Turekian, K.K. 2004. The effect of weathering regime on uranium decay series and osmium in two soil profiles. Geochemical Journal 38, 651-660.

Ku, T.-L., Liang, Z.-C., 1984. The dating of impure carbonates with decay-series isotopes. Nuclear Instruments and Methods in Physics Research 223, 563-571.

Lackner, K. S., Wendt, C. H., Butt, D. P., Joyce, E. L., Sharp, D. H., 1995. Carbon dioxide disposal in carbonate minerals. Energy 20, 1153-1170.

Lackner, K. S., 2002. Carbonate chemistry for sequestering fossil carbon. Annual Review of Energy and the Environment 27, 193-232.

Langmuir, D., Herman, J. S., 1980. The mobility of thorium in natural waters at low temperatures. Geochimica et Cosmochimica Acta 44, 1753-1766.

Le Roux, L. J., Glendenin, L. E., 1963. Half-life of ${ }^{232}$ Th, Proc. Natl. Meet. Nucl. Energy, 83-94.

Lippard, S. J., Shelton, A. W., Gass, I. G., 1986 The Ophiolite of Northern Oman. The Geological Society, Memoir No. 11. Blackwell Scientific Publications, London.

Lively, R. S., Harmon, R. S., Levinson, A. A., Bland, C. J., 1979. Disequilibrium in the ${ }^{238}$ Uranium series in samples from Yeelirrie, Western Australia. Journal of Geochemical Exploration 12, 57-65.

Ludwig, K. R., Titterington, D. M., 1994. Calculation of ${ }^{230} \mathrm{Th} / \mathrm{U}$ isochrons, ages, and errors. Geochimica et Cosmochimica Acta 58: 5031-5042.

Ludwig, K. A., Kelley, D. S., Butterfield, D. A., Nelson, B. K., Früh-Green, G. L., 2006. Formation and evolution of carbonate chimneys at the Lost City hydrothermal field. Geochimica et Cosmochimica Acta 70, 3625-2645.

Ludwig, K. A., Shen, C.-C., Kelley, D. S., Cheng, H., Edwards, L. R., 2011. U-Th systematics and ${ }^{230} \mathrm{Th}$ ages of carbonate chimneys at the Lost City hydrothermal field. Geochimica et Cosmochimica Acta 75, 1869-1888.

Luo, Y., Ku, T.-L., 1991. U-series isochron dating: A generalized method employing total sample dissolution. Geochimica et Cosmochimica Acta 55, 555-564.

Ma, L., Chabaux, F., Pelt, E., Blaes, E., Jin, L., and Brantley, S. 2010. Regolith production rates calculated with uranium-series isotopes at Susquehanna/Shale Hills Critical Zone Observatory. Earth and Planetary Science Letters 297, 211-225. 
Mathieu, D., Bernat, M., and Nahon, D. 1995. Short-lived U and Th isotope distribution in a tropical laterite derived from granite (Pitinga river basin, Amazonia, Brazil): Application to assessment of weathering rate. Earth and Planetary Science 100 Letters 136, 703-714.

Matter, J. M. and Kelemen, P. B., 2009. Permanent storage of carbon dioxide in geological reservoirs by mineral carbonation. Nature Geoscience 2, 837-841.

Mervine, E. M., Humphris, S. E., Sims, K. W. W., Kelemen, P. K., Jenkins, W. J., 2014.

Carbonation rates of peridotite in the Samail Ophiolite, Sultanate of Oman, constrained through

${ }^{14} \mathrm{C}$ dating and stable isotopes. Geochimica et Cosmochimica Acta 126, 371-397.

Mitchell, R. H., 1986. Kimberlites: Mineralogy, Geochemistry, and Petrology. Plenum Press, New York.

Neal, C., Stanger, G., 1983. Hydrogen generation from mantle source rocks in Oman. Earth and Planetary Science Letters 66, 315-320.

Neal, C., Stanger, G., 1984. Calcium and magnesium-hydroxide precipitation from alkaline groundwaters in Oman, and their significance to the process of serpentinization. Mineralogical Magazine 48, 237-241.

Neal, C., Stanger, G., 1985. Past and present serpentinization of ultramafic rocks: An example from the Semail ophiolite nappe of northern Oman. In: Drewer, J. I. (Ed.), The Chemistry of Weathering. D. Reidel Publishing Company, Holland, pp. 249-275.

Nicolas, A., Boudier, F., Ildefonse, V., Ball, E., 2000. Accretion of Oman and United Arab Emirates ophiolite-Discussion of a new structural map. Marine Geophysical Researches 21, 147-149.

Osmond, J. K., May, J. P., Tanner, W. F., 1970. Age of the Cape Kennedy Barrier-and-Lagoon Complex. Journal of Geophysical Research 75, 469-479.

Paukert, A. N., Matter, J. M., Kelemen, P. B., Shock, E. L., Havig, J. R. 2012. Reaction path modeling of enhanced in situ $\mathrm{CO}_{2}$ mineralization for carbon sequestration in the peridotite of the Samail Ophiolite, Sultanate of Oman. Chemical Geology 330-331, 86-100.

Pelt, E., Chabaux, F., Innocent, C., Navarre-Sitchler, A.K., Sak, P.B., and Brantley, S.L. 103 2008. Uranium-thorium chronometry of weathering rinds: Rock alteration rate 104 and paleoisotopic record of weathering fluids. Earth and Planetary Science 105 Letters 276, 98-105.

Peretti, A., Dubessy, J., Mullis, J., Frost, B. R., Tromsdorff, V., 1992. Highly reducing conditions during alpine metamorphism of the Malenco peridotite (Sondiro, northern Italy) indicated by mineral paragenesis and $\mathrm{H}_{2}$ in fluid inclusions. Contributions to Mineralogy and Petrology 112, 329-340. 
Porcelli, D., Swarzneski, P. W., 2003. The behavior of U- and Th-series nuclides in groundwater. In: Bourdon, B., Henderson, G. M., Lundstrom, C. C., Turner, S. P. (Ed.), Uranium-Series Geochemistry. Reviews in Mineralogy and Geochemistry 52, 363-406.

Power I. M., Wilson S. A., Thom J. M., Dipple G. M., Gabites J. E. and Southam G., 2009. The hydromagnesite playas of Atlin, British Columbia, Canada: A biogeochemical model for $\mathrm{CO}_{2}$ sequestration. Chemical Geology 260, 286-300.

Pronost, J., Beaudoin, G., Tremblay, J., Larachi, F., Duchesne, J., Hébert, R., Constantin, M., 2011. Carbon sequestration kinetic and storage capacity of ultramafic mining waste. Environmental Science and Technology 45, 9413-9420.

Przybylowicz, W., Schwarcz, H. P., Latham, A. G., 1991. Dirty Calcites 2. Uranium series dating of artificial calcite-detritus mixtures. Chemical Geology 86, 161-178.

Rasbury, E. T., Cole, J. M., 2009. Directly dating geologic events: U-Pb dating of carbonates. Reviews of Geophysics 47: 1-27.

Robinson, C. S., Rosholt, J. N., 1961. Uranium migration and geochemistry of uranium deposits in sandstone above, at, and below the water table. Part II: Relationship of uranium migration dates, geology, and chemistry of the ore deposits. Economic Geology 56, 1404-1420.

Rosholt, J. N., 1961. Uranium migration and geochemistry of uranium deposits in sandstone at, above, and below the water table. Part I: Calculation of apparent dates of uranium migration in deposits above and at the water table. Economic Geology 56, 1392-1403.

Rosholt, J. N., Harshman, E. N., Shields, W. R., Garner, E. L., 1964. Isotopic fractionation of uranium related to roll features in sandstone, Shirley Basin, Wyoming. Economic Geology 59, 570-585.

Rosholt, J.N., Doe, B.R., and Tatsumoto, M. 1966. Evolution of the isotopic composition of uranium and thorium in soil profiles. Geological Society of America Bulletin 77, 987-1004.

Rosholt, J.N., Bush, C.A., Shroba, R.R., Pierce, K.L., and Richmond, G.M. 1985. Uranium-trend dating and calibrations for Quaternary sediments. Open-File Report 85-299, U.S. Geological Survey, Lakewood, Colorado, pp. 48

Scholz, D., Hoffmann, D., 2008. ${ }^{230} \mathrm{Th} / \mathrm{U}$-dating of fossil corals and speleothems. Quaternary Science Journal 57, 52-76.

Schwarcz, H. P., Lathan, A. G., 1989. Dirty Calcites 1. Uranium-series dating of contaminated calcite using leachates alone. Chemical Geology 80, 35-42.

Searle, M. P., Cox, J., 1999. Tectonic setting, origin, and obduction of the Oman ophiolite. Geological Society of America Bulletin 111, 104-122. 
Searle, M. P., Cox, J., 2002. Subduction zone metamorphism during formation and emplacement of the Semail ophiolite in the Oman Mountains. Geological Magazine 139, 241-255.

Seifritz W., 1990. $\mathrm{CO}_{2}$ disposal by means of silicates. Nature 345, 486.

Sims, K. W. W., Hart, S. R., Reagen, M. K., Blusztajn, J., Staudigel, H., Sohn, R. A., Layne, G. D., Ball, L. A., Andrews, J., 2008a. ${ }^{238} \mathrm{U}^{230} \mathrm{Th}-{ }^{226} \mathrm{Ra}-{ }^{210} \mathrm{~Pb}-{ }^{210} \mathrm{Po},{ }^{232} \mathrm{Th}-{ }^{228} \mathrm{Ra}$, and ${ }^{235} \mathrm{U}-{ }^{231} \mathrm{~Pa}$ constraints on the ages and petrogenesis of Vailulu'u and Malumalu Lavas, Samoa. Geochemistry, Geophysics, Geosystems 9, 1-30.

Sims, K. W. W., Gill, J. B., Dosseto, A., Hoffman, D. L., Lundstrom, C. C., Williams, R. W., Ball, L., Tollstrup, D., Turner, S., Prytulak, J., Glessner, J. J. G., Standish, J. J., Elliot, T., $2008 b$. An inter-laboratory assessment of the thorium isotopic composition of synthetic and rock reference materials. Geostandards and Geoanalytical Research 32, 65-91.

Streit, E., Kelemen, P., Eiler, J., 2012 Coexisting serpentine and quartz from carbonate-bearing serpentinized peridotite in the Samail Ophiolite, Oman. Contributions to Mineralogy and Petrology 164, 821-837.

Surour, A. A., Arafa, E. H., 1997. Ophicarbonates: Calichified serpentinites from Gebel Mohagara, Wadi Ghadir area, Eastern Desert, Egypt. Journal of African Earth Sciences 24, 315324.

Szabo, B. J., Rosholt, J. N., 1982. Surficial continental sediments. In: Ivanovich, M., Harmon, R. S. (Eds.), Uranium Series Disequilibrium: Applications to Environmental Problems. London, Claredon Press, pp. 257-260.

Thompson, W. G., Spiegelman, M. W., Goldstein, S. L., Speed, R. C., 2003. An open system model for U-series age determinations of fossil corals. Earth and Planetary Science Letters 210, 365-381.

Trommsdorff, V., Evans, B. W., 1977. Antigorite-ophicarbonates: Contact metamorphism in Valmalenco, Italy. Contributions to Mineralogy and Petrology 62, 301-312.

Trommsdorff, V., Evans, B. W., Pfeifer, H. R., 1980. Ophicarbonate rocks: Metamorphic reactions and a possible origin. Archives des Sciences Genève 33, 361-364.

Villemant, B., Feuillet, N., 2003. Dating open systems by the ${ }^{238} \mathrm{U}_{-}{ }^{234} \mathrm{U}_{-}{ }^{230} \mathrm{Th}$ method: application to Quaternary reef terraces. Earth and Planetary Science Letters 210, 105-118.

Wilson, S. A., Raudseep, M., Dipple, G. M., 2006. Verifying and quantifying carbon fixation in minerals from serpentine-rich mine tailings using the Rietveld method with X-ray powder diffraction data. American Mineralogist 91, 1331-1341.

Wilson, S. A., Raudsepp, M., Dipple, G. M., 2009a. Quantifying carbon fixation in trace minerals from processed kimberlite: A comparative study of quantitative methods using X-ray 
powder diffraction data with applications to the Diavik Diamond Mine, Northwest Territories, Canada. Applied Geochemistry 24, 95-112.

Wilson, S. A., Dipple, G. M., Power, I. M., Thom, J. M., Anderson, R. G., Raudsepp, M., Gabites, J. E., Southam, G., 2009b. Carbon dioxide fixation within mine wastes of ultramafic hosted ore deposits: Examples from the Clinton Creek and Cassiar chrysotile deposits, Canada. Economic Geology 104, 95-112.

Woodhead, J., Pickering, R., 2012. Beyond 500 ka: Progress and prospects in the U-Pb chronology of speleothems, and their application to studies in paleoclimate, human evolution, biodiversity, and tectonics. Chemical Geology 322-323: 290-299.

\section{List of tables}

Table 1: Sample Locations and Descriptions

Table 2: $\mathbf{U}$ and Th Concentrations. $U$ and Th concentrations were measured by isotope dilution using a Thermo Fisher Element 2 high resolution sector-field ICP-MS at WHOI. Mass fractionation was corrected by sample-standard bracketing with NBL-112A, using a linear interpolation of ${ }^{235} \mathrm{U} /{ }^{238} \mathrm{U}$ measurements of the standard. Errors include uncertainties in spike calibrations, in run measurement error, and uncertainty in standards against which instrument measurements were calibrated.

Table 3: U and Th Isotopic Values Isotopic compositions were measured with a Thermo Fisher Neptune MC-ICP-MS at WHOI. ${ }^{232}$ Th and ${ }^{238} \mathrm{U}$ were measured on a Faraday cup and ${ }^{230} \mathrm{Th}$ on an axial, discrete dynode ion counter with a repelling potential quadrupole (RPQ). Abundance sensitivity over 2 AMU at $85 \%$ transmission was $\sim 50 \mathrm{ppb}$. An exponential correction was used to correct for the tailing of ${ }^{232} \mathrm{Th}$ on ${ }^{230} \mathrm{Th}$. Use of UCSC Th 'A' for Th-bracketing results in inter-day reproducibility of $0.4-1.5 \%$ $(2 \sigma) .{ }^{236} \mathrm{U} /{ }^{238} \mathrm{U}$ ratios of U010 were measured to correct for mass bias drift and to calibrate SEM yield. Standard-sample-standard bracketing was used for uranium analyses.

( ) denotes activity. Activity ratios calculated using: $\lambda_{230}=9.158 \times 10^{-6} \mathrm{yr}-1$ (Cheng et al., 2000); $\lambda_{232}=4.948 \times 10^{-11} \mathrm{yr}-1$ (Le Roux and Glendenin, 1963); $\lambda_{234}=2.8263 \times 10^{-6} \mathrm{yr}-1$ (Cheng et al., 2000); and, $\lambda_{238}=1.551 \times 10^{-10} \mathrm{yr}-1$; (Jaffey et al., 1971).

Errors for activitiy ratios include uncertainties in spike calibrations for ${ }^{232} \mathrm{Th}$ and ${ }^{238} \mathrm{U}$ concentrations, in run measurement error for ${ }^{230} \mathrm{Th} /{ }^{232} \mathrm{Th}$ and uncertainties in the standards against which instrument measurements were calibrated. Errors do not include uncertainties in $\lambda_{238}(0.07 \%), \lambda_{232}(0.5 \%), \lambda_{230}(0.3 \%)$ or $\lambda_{234}(0.1 \%)$.

\section{List of figures}

Figure 1: The eight field locations (blue circles) where carbonate and peridotite samples were collected in the Samail Ophiolite during 2009 and 2010 field seasons. Map made using ArcGIS, Version 10.1. 
Figure 2: Schematic illustrating the behavior of $\mathrm{CO}_{2}, \mathrm{U}$, and Th in Type I and Type II waters associated with alteration of partially-serpentinized peridotite. Figure modified from Neal and 1217 Stanger (1985).

1218 Figure 3: Representative images of carbonates and altered peridotites in the Samail Ophiolite. A: Recently-formed travertine precipitate in a hyperalkaline streambed at Qafeefah Travertine. B: A turquoise hyperalkaline pool and recently-formed travertine precipitate at Wadi Sudari Travertine. Note the hammer for scale. C: Small hills of altered peridotite (background) adjacent to travertine terraces at Misht Travertine. D: Calcite-rich travertine veins exposed underneath a $\sim 1$ to $2 \mathrm{~m}$ thick travertine terrace deposit at Wadi Sudari Travetine. The veins can be seen in the overhang, next to the person. E: A white magenesite vein with botryoidal texture exposed on the natural peridotite weathering surface near Fanja Roadcut. Note the hammer for scale. F: Dolomite-serpentine veins exposed on the surface of Fanja Roadcut. Note the marker for scale. G: Very highly altered peridotite exposed underneath a travertine terrace at Misht Travertine. $\mathrm{H}$ : Highly altered peridotite exposed at Misht Travertine. Note the hammer for scale.

Figure 4: Plot of $U$ and Th concentrations for Samail travertines (orange circles for travertine terraces, pink circles for recently-formed travertine precipitates, orange triangles for travertine pseudospeleothems, and an orange square for the travertine vein), Mg-rich carbonate veins (blue circles for Mg-rich carbonate outcrop veins and blue squares for Mg-rich carbonate roadcut veins), serpentine mineral separates from carbonate-serpentine veins (purple circles), and wadi sediments (brown triangles). Note that both axes have a log scale. Shown for reference are U and Th concentrations for harzburgites (green circles) and dunites (green squares) from Wadi Tayin, a massif in the southern part of the Samail Ophiolite (data from Hanghøj et al., 2010); for carbonates formed at Lost City, a hydrothermal site located in peridotite $\sim 15 \mathrm{~km}$ off-axis of the Mid-Atlantic Ridge (data from Ludwig et al., 2011); and for speleothems from Hoti Cave, which is located in Cretaceous age Natih limestone in northern Oman (data from Fleitmann et al., 2003).

Figure 5: Plot of $\left({ }^{230} \mathrm{Th} /{ }^{232} \mathrm{Th}\right)$ versus $\left({ }^{238} \mathrm{U} /{ }^{232} \mathrm{Th}\right)$ for Samail travertines, Mg-rich carbonate veins, highly altered peridotites, and wadi sediments using the same symbol scheme as Figure 4.

Figure 6: Plot of $\left({ }^{234} \mathrm{U} /{ }^{238} \mathrm{U}\right)$ versus $\mathrm{U}$ concentration for Samail travertines, Mg-rich carbonate veins, and wadi sediments using the same symbol scheme as Figure 4. The dashed line indicates equilibrium for $\left({ }^{234} \mathrm{U} /{ }^{238} \mathrm{U}\right)$.

1246 Figure 7: Plot of $\left({ }^{230} \mathrm{Th} /{ }^{232} \mathrm{Th}\right)$ versus Th concentration for Samail travertines, Mg-rich carbonate veins, and wadi sediments using the same symbol scheme as Figure 4.

Figure 8: Sensitivity analysis figure showing the effect of the selected detritus $\left({ }^{230} \mathrm{Th} /{ }^{232} \mathrm{Th}\right)$ correction value on the corrected ${ }^{230} \mathrm{Th}$ age. This figure is for sample OM09-106C-MS-A, a travertine terrace sample from Wadi Uqaybah. The blue line indicates the corrected ${ }^{230} \mathrm{Th}$ age calculated from the detritus value on the $\mathrm{x}$-axis. Note that the uncorrected ${ }^{230}$ Th age plots at $\mathrm{x}=$ 0 . For comparison, the calibrated ${ }^{14} \mathrm{C}$ age (from Mervine et al., 2014) is plotted as the red line. The gray box indicates the $2 \sigma$ range of $\left({ }^{230} \mathrm{Th} /{ }^{232} \mathrm{Th}\right.$ ) values for aluminosilicate detritus (a 1254 literature compilation of $\sim 300$ values, see Supplementary Information). The vertical lines 
1255 indicate possible values to use for the detritus $\left({ }^{230} \mathrm{Th} /{ }^{232} \mathrm{Th}\right)$ correction value: the average of the 1256 aluminosilicate detritus literature compilation (yellow line), equilibrium Bulk Silicate Earth 1257 (pink line), wadi sediments (green lines), and recently-formed travertine precipitates (black 1258 lines). The choice of the $\left({ }^{230} \mathrm{Th} /{ }^{232} \mathrm{Th}\right)$ correction value has a very significant impact on the 1259 determined ${ }^{230} \mathrm{Th}$ age, which ranges from $\sim 50,000$ years to zero depending on the correction 1260 value selected. However, a $\left({ }^{230} \mathrm{Th} /{ }^{232} \mathrm{Th}\right)$ correction value of approximately 1.7 brings the 1261 corrected ${ }^{230} \mathrm{Th}$ age into concordance with the ${ }^{14} \mathrm{C}$ age.

1262 Figure 9: Sensitivity analysis figure showing the effect of the selected detritus $\left({ }^{230} \mathrm{Th} /{ }^{232} \mathrm{Th}\right)$ 1263 correction value on the corrected ${ }^{230} \mathrm{Th}$ age. This figure is for sample OM10-13C-MG, an Mg1264 rich carbonate outcrop vein from Fanja Roadcut. The blue line indicates the corrected ${ }^{230} \mathrm{Th}$ age 1265 1266 calculated from the detritus value on the $\mathrm{x}$-axis. Note that the uncorrected ${ }^{230} \mathrm{Th}$ age plots at $\mathrm{x}=$ 0 . For comparison, the calibrated ${ }^{14} \mathrm{C}$ age (from Mervine et al., 2014) is plotted as the red line. The gray box indicates the $2 \sigma$ range of $\left({ }^{230} \mathrm{Th} /{ }^{232} \mathrm{Th}\right.$ ) values for aluminosilicate detritus (a literature compilation of $\sim 300$ values, see Supplementary Information). The vertical lines indicate possible values to use for the detritus $\left({ }^{230} \mathrm{Th} /{ }^{232} \mathrm{Th}\right)$ correction value: the average of the aluminosilicate detritus literature compilation (yellow line), equilibrium Bulk Silicate Earth (pink line), wadi sediments (green lines), and recently-formed travertine precipitates (black lines). The choice of the $\left({ }^{230} \mathrm{Th} /{ }^{232} \mathrm{Th}\right)$ correction value has a very significant impact on the determined ${ }^{230} \mathrm{Th}$ age, which ranges from $\sim 30,000$ years to zero depending on the correction value selected. Since the uncorrected ${ }^{230} \mathrm{Th}$ age is younger than the ${ }^{14} \mathrm{C}$ age, no $\left({ }^{230} \mathrm{Th} /{ }^{232} \mathrm{Th}\right)$ correction value can bring the two ages into concordance.

Figure 10: Sensitivity analysis figure showing the effect of the selected detritus $\left({ }^{230} \mathrm{Th} /{ }^{232} \mathrm{Th}\right)$ correction value on the corrected ${ }^{230} \mathrm{Th}$ age. This figure is for sample OM09-57C-MS, an Mgrich carbonate roadcut vein from Fanja Roadcut. The blue line indicates the corrected ${ }^{230} \mathrm{Th}$ age calculated from the detritus value on the $\mathrm{x}$-axis. Note that the uncorrected ${ }^{230} \mathrm{Th}$ age plots at $\mathrm{x}=$ 0 . For comparison, the calibrated ${ }^{14} \mathrm{C}$ age (from Mervine et al., 2014) is plotted as the red line. The gray box indicates the $2 \sigma$ range of $\left({ }^{230} \mathrm{Th} /{ }^{232} \mathrm{Th}\right.$ ) values for aluminosilicate detritus (a literature compilation of $\sim 300$ values, see Supplementary Information). The vertical lines indicate possible values to use for the detritus $\left({ }^{230} \mathrm{Th} /{ }^{232} \mathrm{Th}\right)$ correction value: average of aluminosilicate detritus literature compilation (yellow line), equilibrium Bulk Silicate Earth (pink line), wadi sediments (green lines), and recently-formed travertine precipitates (black lines). The choice of the $\left({ }^{230} \mathrm{Th} /{ }^{232} \mathrm{Th}\right)$ correction value has a minimal impact on the determined ${ }^{230} \mathrm{Th}$ age, which remains greater than 350,000 years. This is consistent with the ${ }^{14} \mathrm{C}$ dead (>50,000 yr BP) age limit of this sample. 


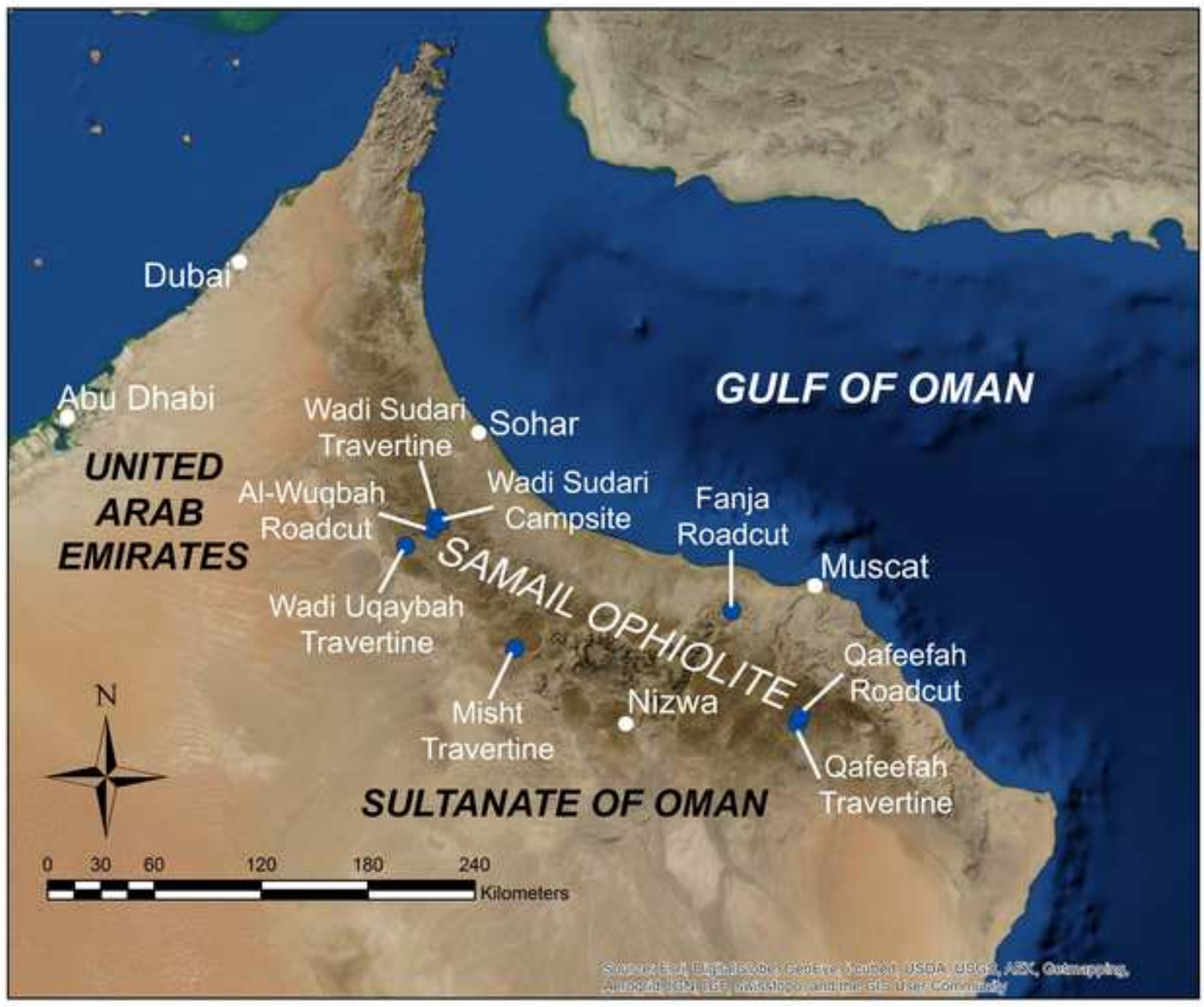




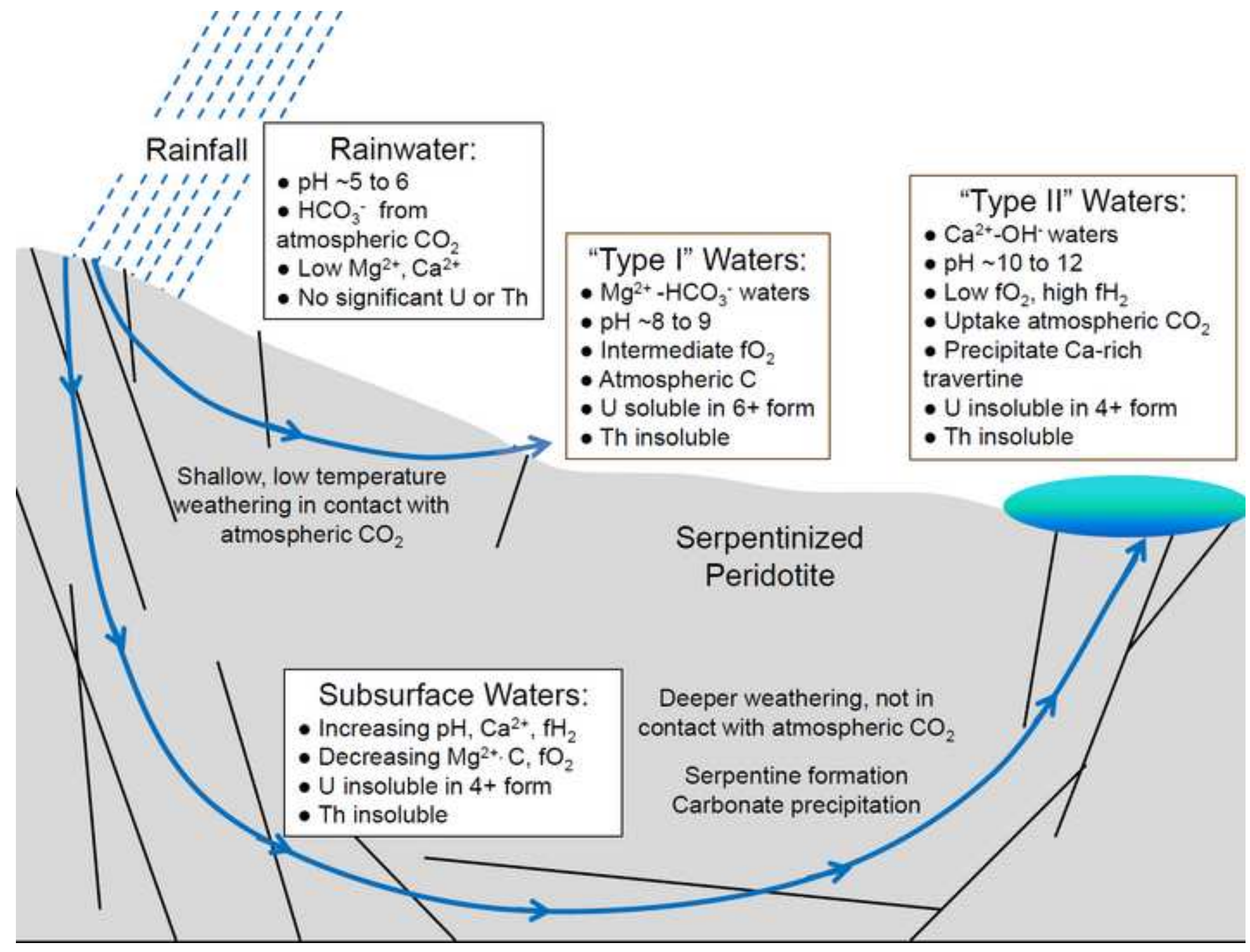




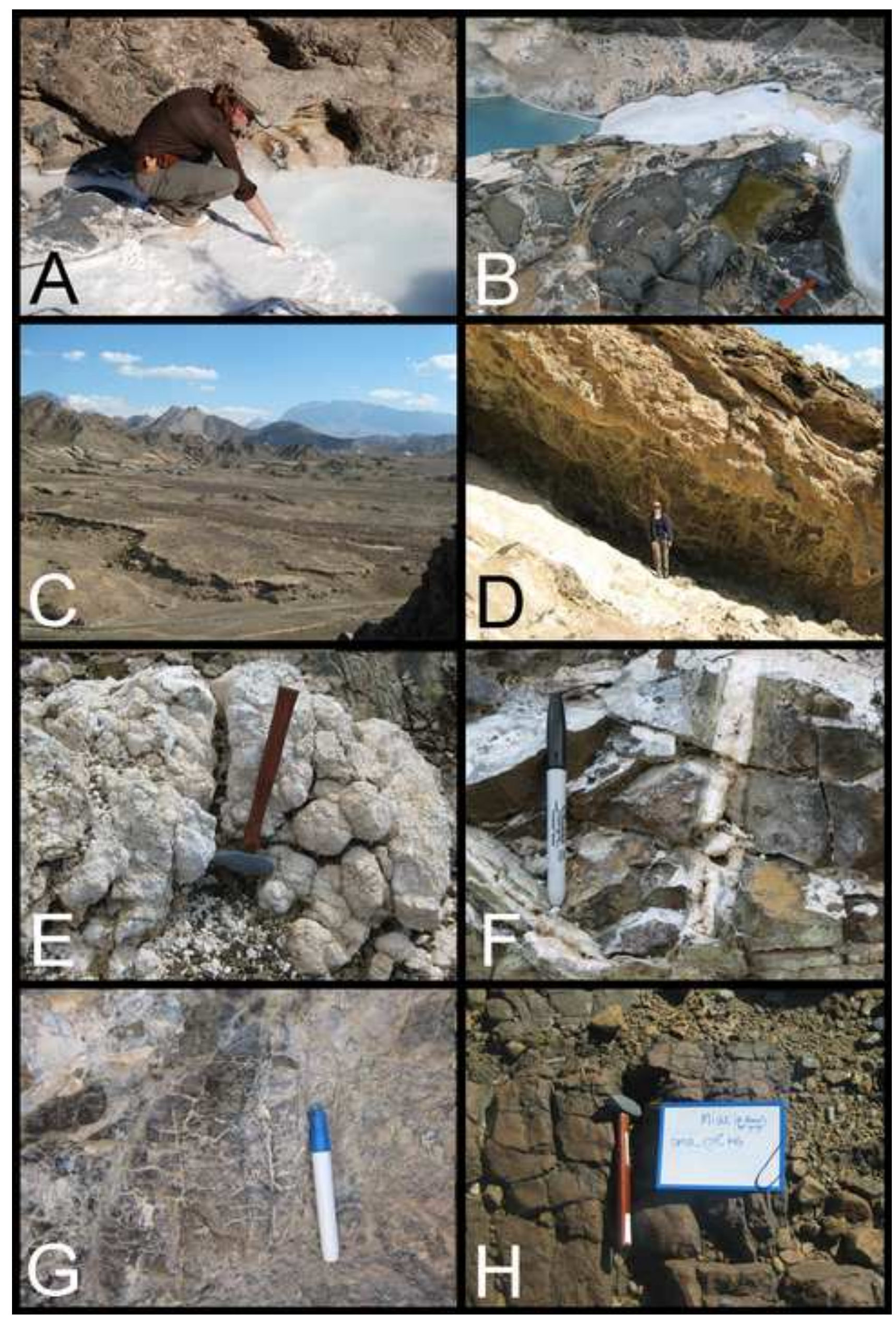

Figure 3 


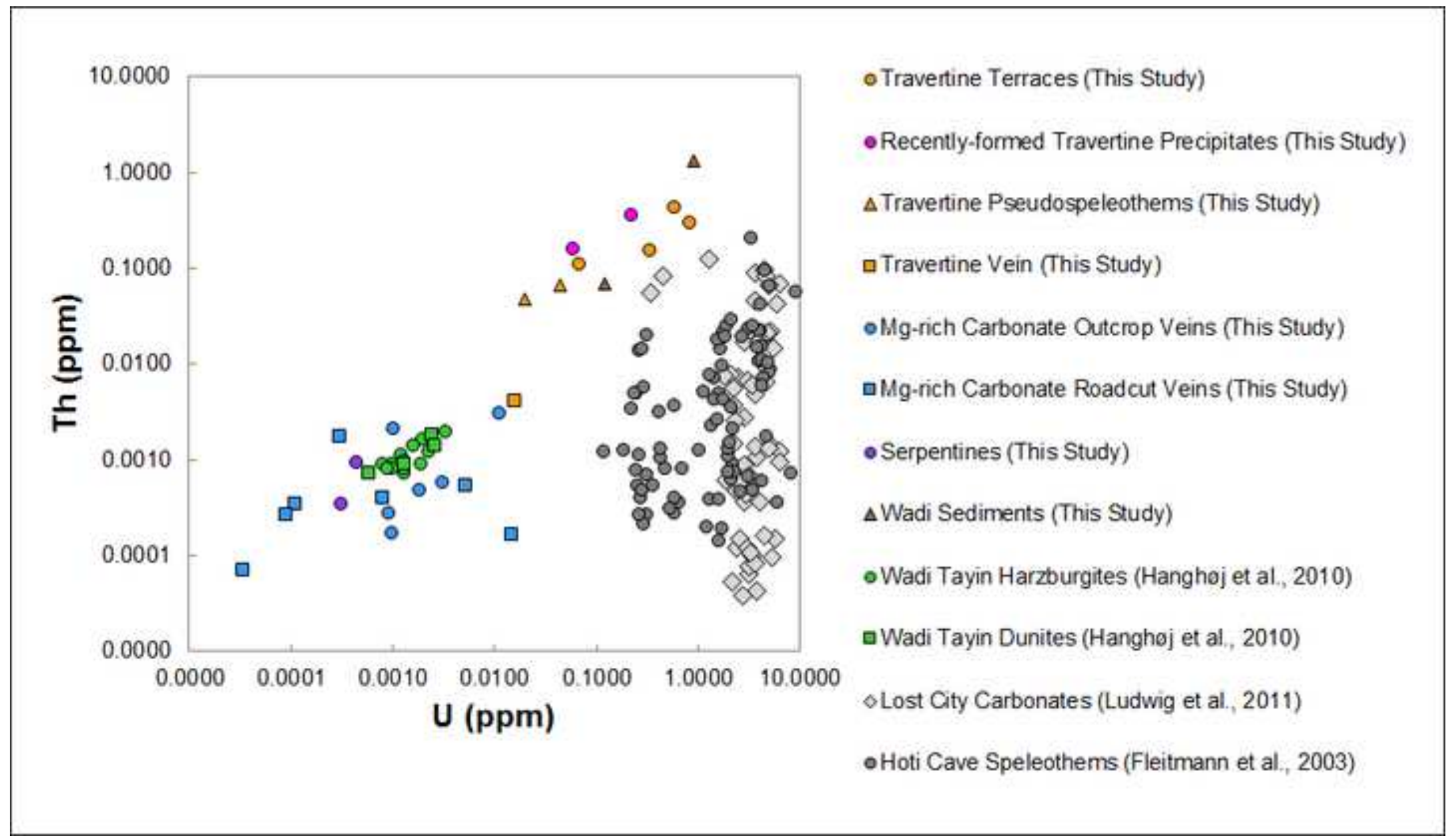




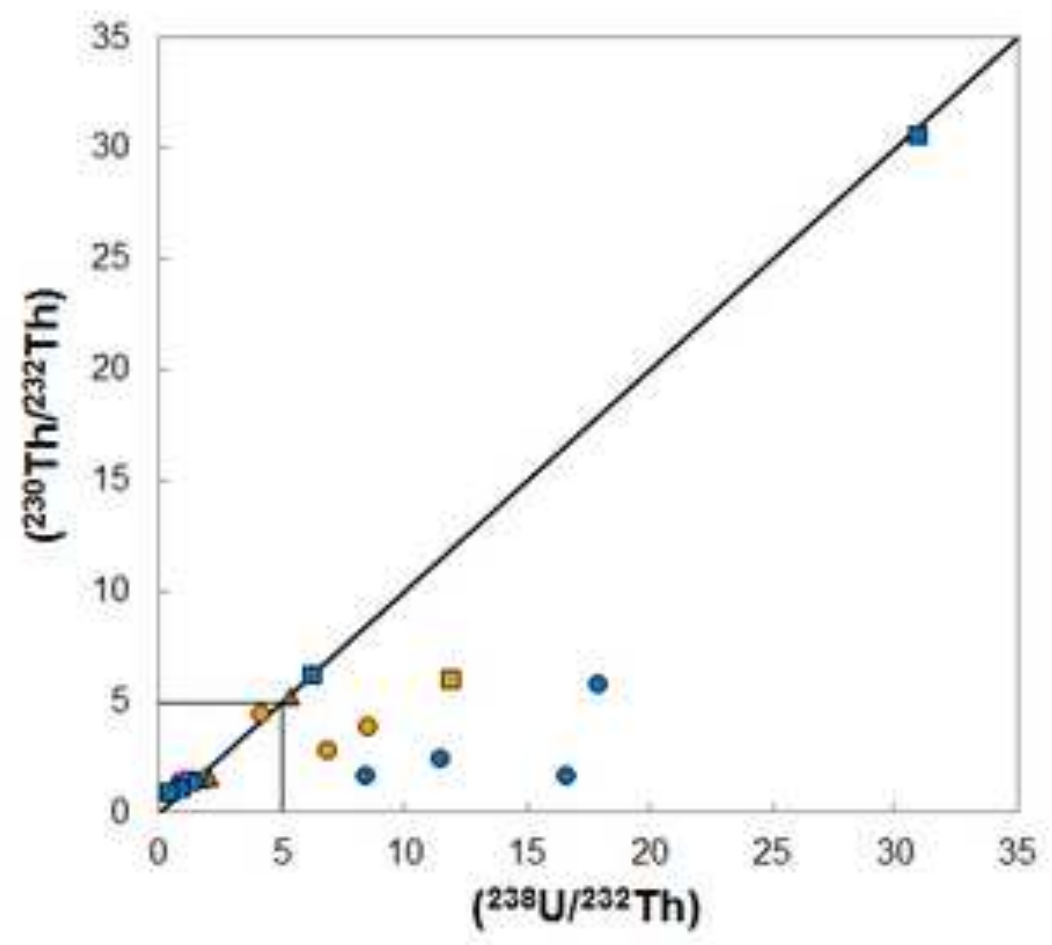

- Travertine Terraces

- Recently-formed Travertine Precipitates

A. Travertine Pseudospeleothems

- Travertine Vein

- Mg-Rich Carbonate Outcrop Veins

- Mg-Rich Carbonate Roadcut Veins

A Wadi Sediments

- Equiline

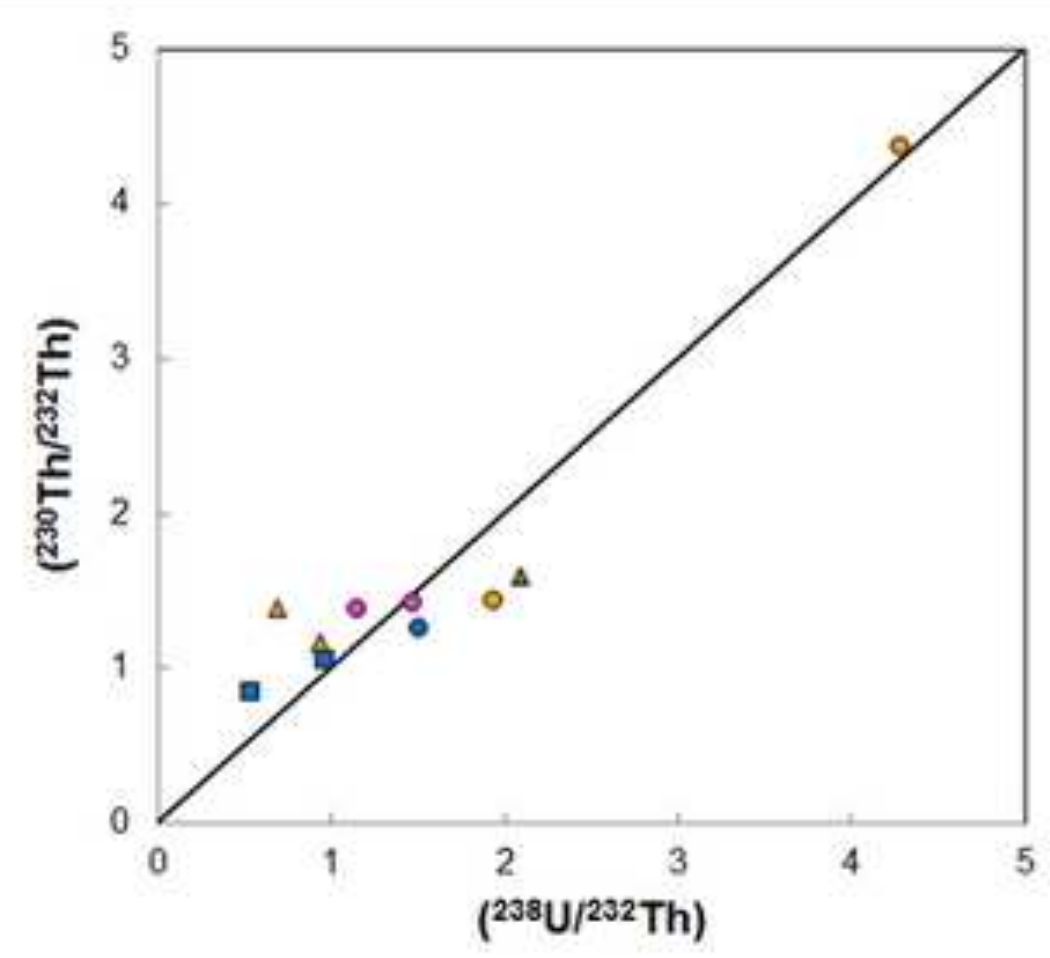

A 


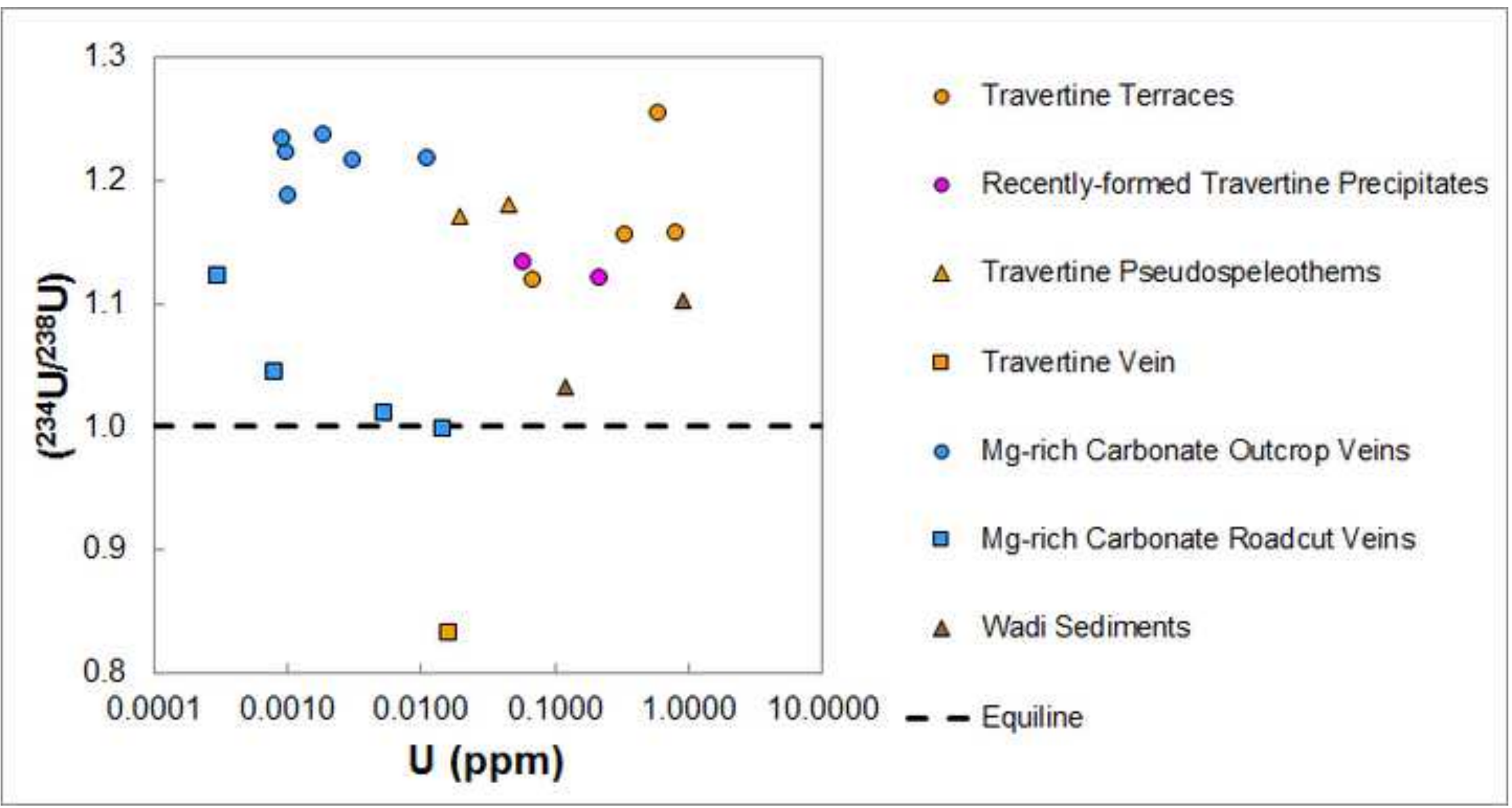




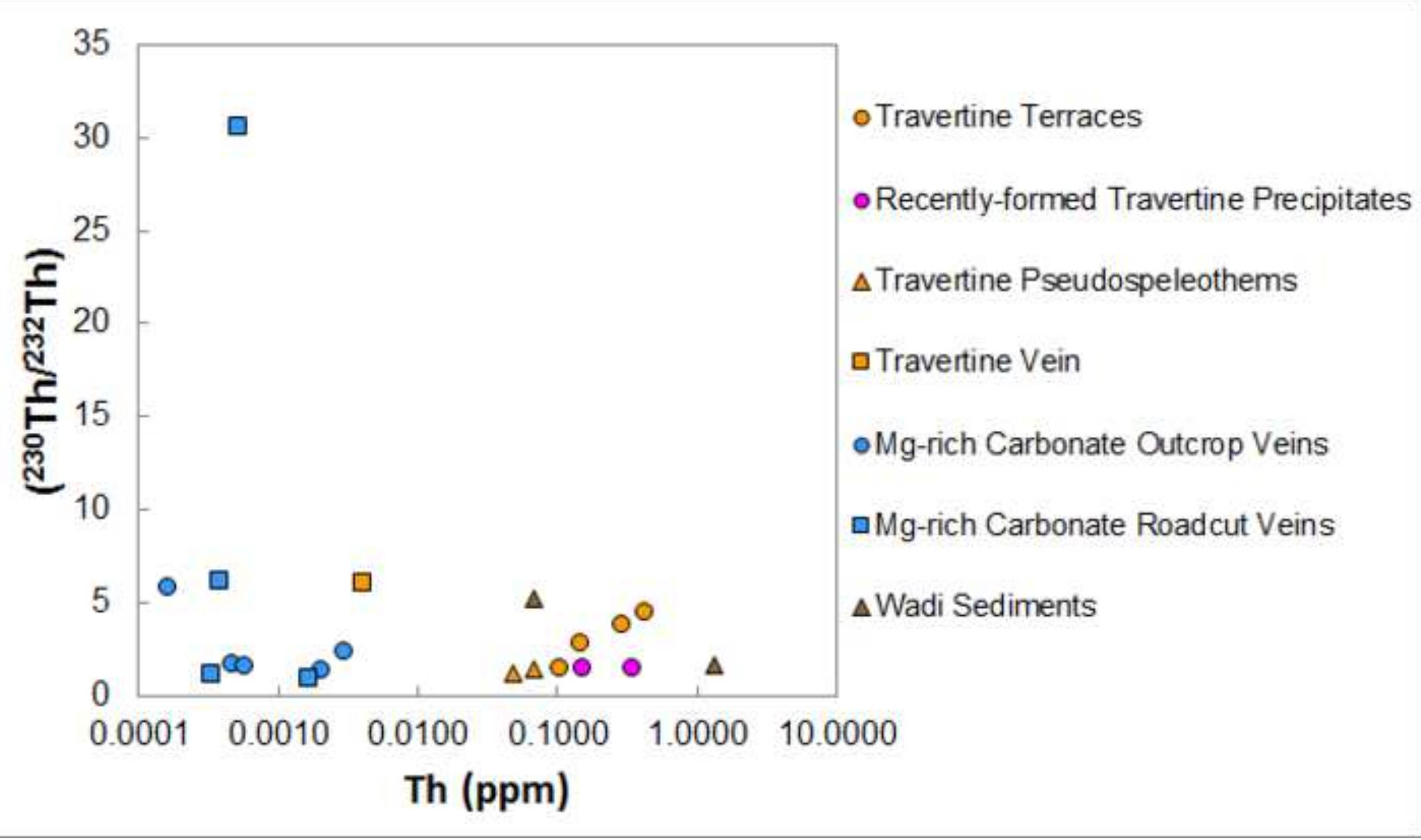




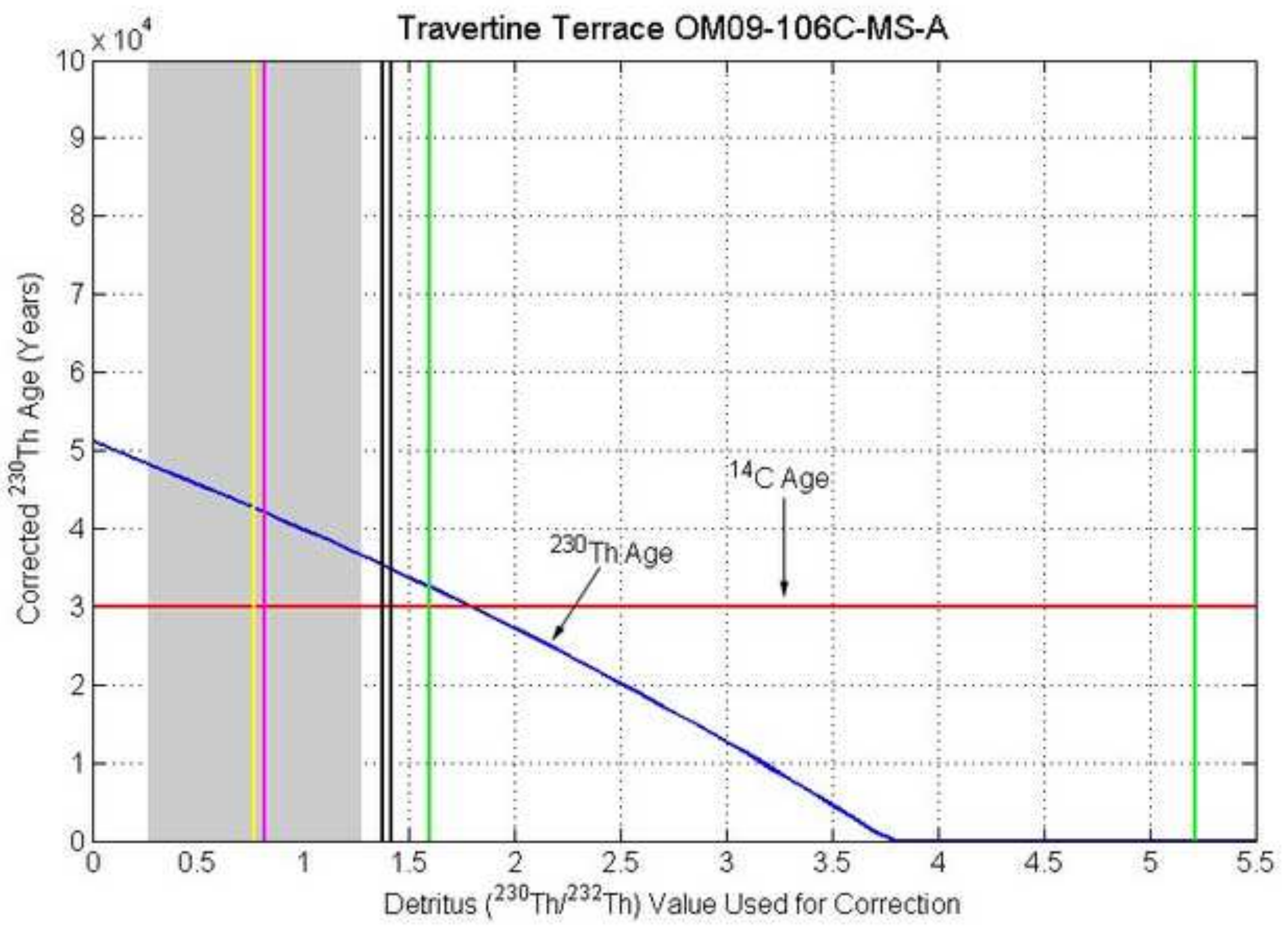




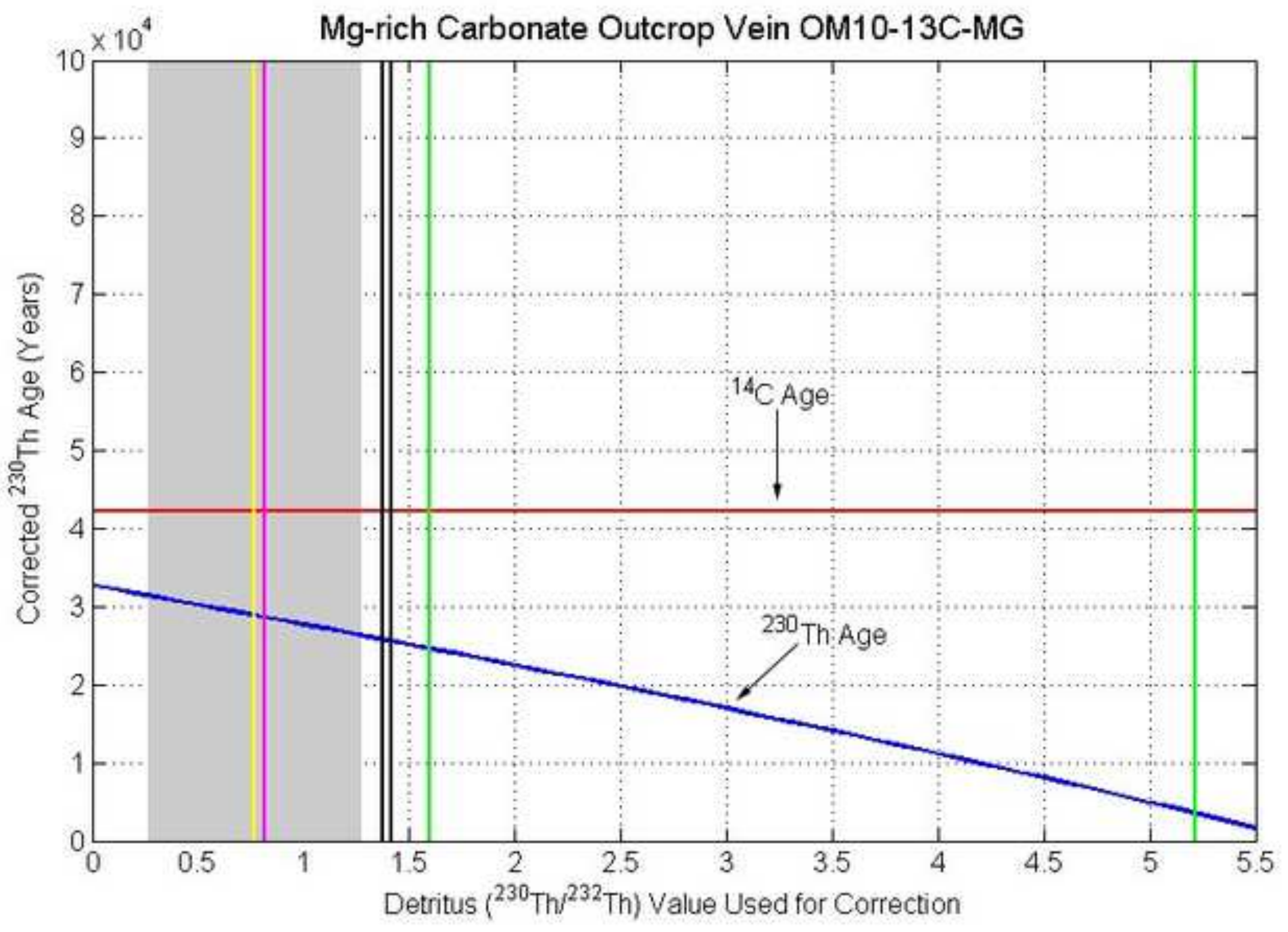




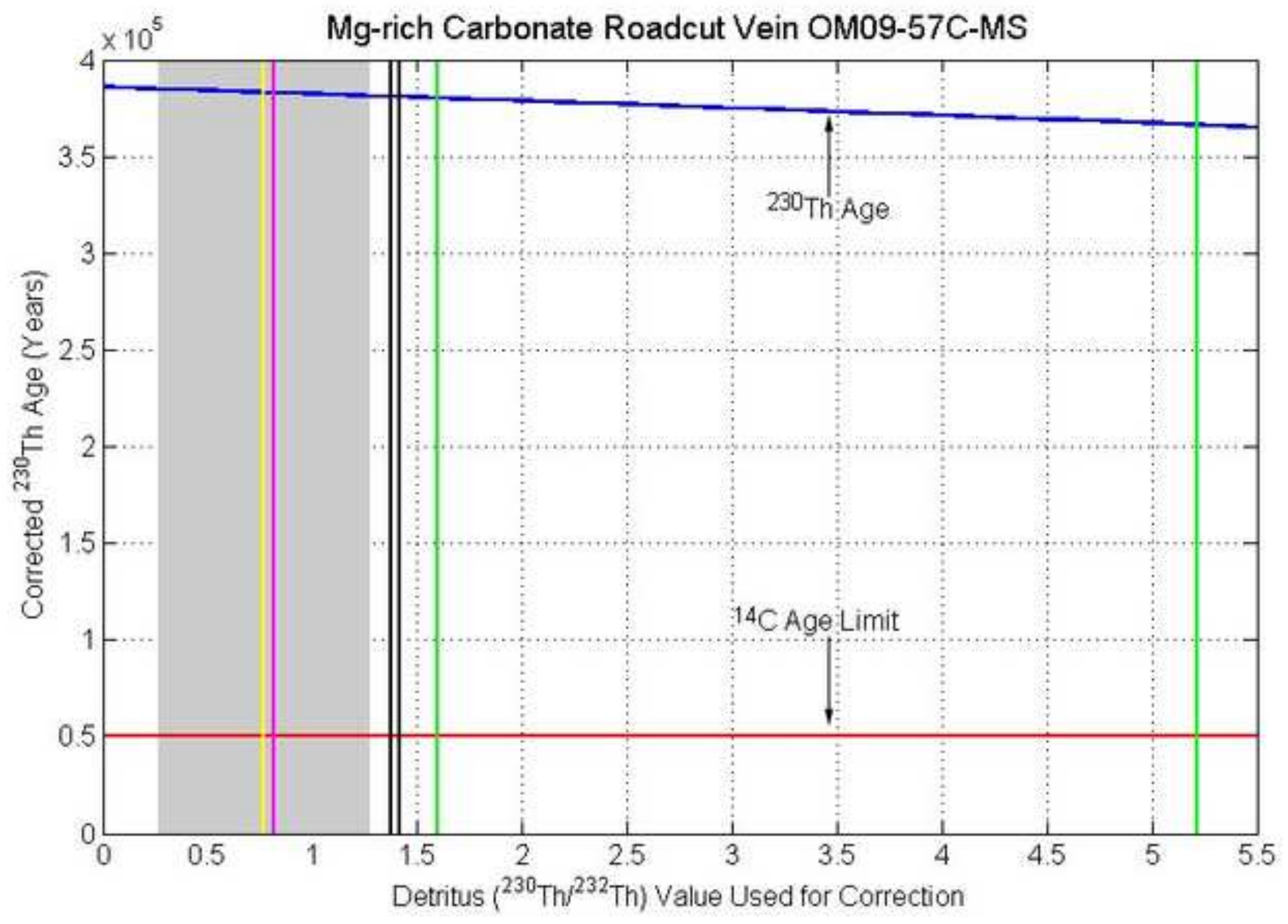




\begin{tabular}{|c|c|c|c|c|c|c|}
\hline Sample Name: & Location: & $\begin{array}{c}\text { UTM- } \\
\text { Easting }\end{array}$ & $\begin{array}{c}\text { UTM- } \\
\text { Northing }\end{array}$ & Description: & $\begin{array}{l}\text { Major Minerals } \\
\text { (XRD): }\end{array}$ & Trace Minerals (XRD): \\
\hline \multicolumn{7}{|l|}{ Travertines: } \\
\hline OM09-76C-MS-A (Top) & $\begin{array}{l}\text { Wadi Sudari } \\
\text { Travertine }\end{array}$ & 0443115 & 2650257 & $\begin{array}{c}\text { Layered } \\
\text { pseudospeleothem (drop) }\end{array}$ & calcite & none \\
\hline $\begin{array}{c}\text { OM09-76C-MS-C } \\
\text { (Bottom) }\end{array}$ & $\begin{array}{l}\text { Wadi Sudari } \\
\text { Travertine }\end{array}$ & 0443115 & 2650257 & $\begin{array}{c}\text { Layered } \\
\text { pseudospeleothem (drop) }\end{array}$ & calcite & unidentified clay \\
\hline OM09-8COPS-MS & $\begin{array}{l}\text { Wadi Sudari } \\
\text { Travertine }\end{array}$ & 0443118 & 2650078 & $\begin{array}{l}\text { Recently-formed travertine } \\
\text { precipitate }\end{array}$ & calcite & $\begin{array}{c}\text { aragonite, hydromagnesite?, } \\
\text { unidentified clay }\end{array}$ \\
\hline OM09-84C-MS & $\begin{array}{l}\text { Wadi Sudari } \\
\text { Travertine }\end{array}$ & 0443082 & 2650304 & Travertine vein & calcite, brucite & $\begin{array}{l}\text { hydromagnesite?, unidentified } \\
\text { clay }\end{array}$ \\
\hline $\begin{array}{l}\text { OM09-106C-MS-A } \\
\text { (Top) }\end{array}$ & $\begin{array}{l}\text { Wadi Uqaybah } \\
\text { Travertine }\end{array}$ & 0426245 & 2633924 & Travertine terrace & calcite & none \\
\hline $\begin{array}{l}\text { OM09-106C-MS-B } \\
\text { (Bottom) }\end{array}$ & $\begin{array}{l}\text { Wadi Uqaybah } \\
\text { Travertine }\end{array}$ & 0426245 & 2633924 & Travertine terrace & calcite & unidentified clay \\
\hline OM09-107C-MS & $\begin{array}{l}\text { Wadi Uqaybah } \\
\text { Travertine }\end{array}$ & 0426309 & 2633950 & Travertine terrace & calcite & unidentified clay \\
\hline OM09-109C-MS & $\begin{array}{l}\text { Wadi Uqaybah } \\
\text { Travertine }\end{array}$ & 0426208 & 2633925 & Travertine terrace & calcite & none \\
\hline OM09-10COPS-MS & $\begin{array}{l}\text { Wadi Uqaybah } \\
\text { Travertine }\end{array}$ & 0426183 & 2633965 & $\begin{array}{l}\text { Recently-formed travertine } \\
\text { precipitate }\end{array}$ & calcite & quartz, unidentified clay \\
\hline \multicolumn{7}{|l|}{$\begin{array}{l}\text { Mg-Rich Carbonate } \\
\text { Outcrop Veins: }\end{array}$} \\
\hline OM09-47C-MS & Fanja Roadcut & 0609304 & 2597565 & Carbonate outcrop vein & magnesite & unidentified clay \\
\hline OM10-13C-MG & Fanja Roadcut & 0609451 & 2597416 & Carbonate outcrop vein & magnesite & dolomite, calcite \\
\hline OM10-53C-MG & $\begin{array}{l}\text { Al-Wuqbah } \\
\text { Roadcut }\end{array}$ & 0440574 & 2643360 & Carbonate outcrop vein & magnesite & none \\
\hline OM09-91C-MS & $\begin{array}{l}\text { Wadi Sudari } \\
\text { Campsite }\end{array}$ & 0446151 & 2647471 & Carbonate outcrop vein & magnesite & calcite \\
\hline OM10-82C-MG & $\begin{array}{l}\text { Wadi Sudari } \\
\text { Campsite }\end{array}$ & 0445905 & 2647602 & Carbonate outcrop vein & magnesite & $\begin{array}{l}\text { dolomite, calcite, unidentified } \\
\text { clay }\end{array}$ \\
\hline OM10-84C-MG & $\begin{array}{l}\text { Wadi Sudari } \\
\text { Campsite }\end{array}$ & 0445991 & 2647684 & Carbonate outcrop vein & brucite, calcite & $\begin{array}{l}\text { magnesite, dolomite, } \\
\text { unidentified clay }\end{array}$ \\
\hline \multicolumn{7}{|l|}{$\begin{array}{l}\text { Mg-Rich Carbonate } \\
\text { Roadcut Veins: }\end{array}$} \\
\hline OM09-35C-MS & Qafeefah Roadcut & 0647852 & 2537682 & Carbonate/serpentine & magnesite & chrysotile, unidentified clay \\
\hline
\end{tabular}




\begin{tabular}{|c|c|c|c|c|c|c|}
\hline & & & & roadcut vein & & \\
\hline OM09-36C-MS & Qafeefah Roadcut & 0647818 & 2537657 & Carbonate roadcut vein & magnesite & calcite, dolomite \\
\hline OM09-55C-MS & Fanja Roadcut & 0609351 & 2597507 & $\begin{array}{c}\text { Carbonate/serpentine } \\
\text { roadcut vein }\end{array}$ & dolomite & aragonite?, unidentified clay \\
\hline OM09-57C-MS & Fanja Roadcut & 0609356 & 2597501 & $\begin{array}{c}\text { Carbonate/serpentine } \\
\text { roadcut vein }\end{array}$ & dolomite & $\begin{array}{c}\text { aragonite?, calcite, unidentified } \\
\text { clay }\end{array}$ \\
\hline OM09-58C-MS & Fanja Roadcut & 0609370 & 2597506 & Carbonate roadcut vein & $\begin{array}{l}\text { dolomite, } \\
\text { periclase? }\end{array}$ & aragonite?, unidentified clay \\
\hline OM09-63C-MS & Fanja Roadcut & 0609470 & 2597481 & Carbonate roadcut vein & magnesite & unidentified clay \\
\hline OM10-52C-MG & $\begin{array}{c}\text { Al-Wuqbah } \\
\text { Roadcut }\end{array}$ & 0440396 & 2643047 & Carbonate roadcut vein & magnesite & halite?, unidenitifed clay \\
\hline \multicolumn{7}{|l|}{ Serpentines: } \\
\hline OM10-27C-MG-SERP & Qafeefah Roadcut & 0647791 & 2537644 & $\begin{array}{l}\text { Carbonate/serpentine } \\
\text { roadcut vein }\end{array}$ & lizardite & none \\
\hline OM10-54C-MG-SERP & $\begin{array}{c}\text { Al-Wuqbah } \\
\text { Roadcut }\end{array}$ & 0440832 & 2643931 & $\begin{array}{c}\text { Carbonate/serpentine } \\
\text { roadcut vein }\end{array}$ & lizardite & none \\
\hline \multicolumn{7}{|l|}{ Sediments: } \\
\hline OM09-8S-MS & Fanja Roadcut & 0609493 & 2597536 & $\begin{array}{l}\text { Sediment collected from } \\
\text { wadi floor }\end{array}$ & lizardite & $\begin{array}{l}\text { quartz, dolomite, magnesite, } \\
\text { calcite }\end{array}$ \\
\hline OM09-12S-MS & $\begin{array}{l}\text { Wadi Uqaybah } \\
\text { Travertine }\end{array}$ & 0426173 & 2633970 & $\begin{array}{l}\text { Sediment collected from } \\
\text { wadi floor }\end{array}$ & quartz, calcite & $\begin{array}{l}\text { chrysotile, dolomite, enstatite, } \\
\text { aragonite? }\end{array}$ \\
\hline \multicolumn{7}{|l|}{ Carbonate Standard: } \\
\hline $\mathrm{JCp}-1$ & $\begin{array}{l}\text { Ryukyu Islands, } \\
\text { Japan }\end{array}$ & & & Porites coral & -- & -- \\
\hline
\end{tabular}




\begin{tabular}{|c|c|c|c|c|c|c|}
\hline Sample Name: & U (ppm): & $2 \sigma(\%):$ & Th (ppm): & $2 \sigma(\%):$ & Th/U: & $2 \sigma(\%):$ \\
\hline \multicolumn{7}{|l|}{ Travertines: } \\
\hline OM09-76C-MS-A (Top) & 0.0447 & 3.14 & 0.0673 & 1.45 & 1.5070 & 3.46 \\
\hline OM09-76C-MS-C (Bottom) & 0.0195 & 1.81 & 0.0472 & 1.83 & 2.4239 & 2.58 \\
\hline OM09-8COPS-MS & 0.0596 & 1.95 & 0.1561 & 1.30 & 2.6202 & 2.35 \\
\hline OM09-84C-MS & 0.0161 & 1.42 & 0.0041 & 1.39 & 0.2532 & 1.99 \\
\hline OM09-106C-MS-A (Top) & 0.8275 & 5.42 & 0.2917 & 1.96 & 0.3525 & 5.77 \\
\hline \multirow[t]{3}{*}{ OM09-106C-MS-B (Bottom) } & 0.3434 & 1.57 & 0.1507 & 2.20 & 0.4389 & 2.70 \\
\hline & 0.3456 & 1.88 & 0.1507 & 1.25 & 0.4361 & 2.26 \\
\hline & 0.3445 & 1.73 & 0.1507 & 1.73 & 0.4375 & 2.48 \\
\hline OM09-107C-MS & 0.6016 & 1.52 & 0.4250 & 1.25 & 0.7065 & 1.96 \\
\hline OM09-109C-MS & 0.0687 & 1.61 & 0.1072 & 1.98 & 1.5607 & 2.55 \\
\hline \multirow[t]{3}{*}{ OM09-10COPS-MS } & 0.2693 & 3.06 & 0.3455 & 4.20 & 1.2829 & 5.19 \\
\hline & 0.1732 & 1.56 & 0.3560 & 1.52 & 2.0551 & 2.18 \\
\hline & 0.2213 & 2.31 & 0.3507 & 2.86 & 1.5852 & 1.24 \\
\hline \multicolumn{7}{|l|}{ Mg-Rich Carbonate Outcrop Veins: } \\
\hline \multirow[t]{3}{*}{ OM09-47C-MS } & 0.0030 & 2.62 & 0.0007 & 2.10 & 0.2317 & 3.36 \\
\hline & 0.0007 & 7.05 & 0.0003 & 3.44 & 0.3547 & 7.85 \\
\hline & 0.0019 & 4.84 & 0.0005 & 2.77 & 0.2554 & 5.60 \\
\hline OM10-13C-MG & 0.0010 & 1.65 & 0.0002 & 4.49 & 0.1683 & 4.78 \\
\hline OM10-53C-MG & 0.0032 & 2.72 & 0.0006 & 2.48 & 0.1819 & 3.69 \\
\hline OM09-91C-MS & 0.0114 & 8.72 & 0.0030 & 12.68 & 0.2626 & 15.39 \\
\hline OM10-82C-MG & 0.0009 & 3.96 & 0.0003 & 2.45 & 0.2903 & 4.66 \\
\hline OM10-84C-MG & 0.0010 & 1.74 & 0.0021 & 2.66 & 1.9955 & 3.18 \\
\hline \multicolumn{7}{|l|}{ Mg-Rich Carbonate Roadcut Veins: } \\
\hline OM09-35C-MS & 0.0001 & 1.43 & 0.0003 & 1.31 & 3.0990 & 1.93 \\
\hline OM09-36C-MS & 0.0001 & 2.11 & 0.0003 & 4.87 & 2.9332 & 5.30 \\
\hline OM09-55C-MS & 0.0008 & 1.86 & 0.0004 & 2.55 & 0.4777 & 3.15 \\
\hline OM09-57C-MS & 0.0053 & 1.46 & 0.0005 & 1.45 & 0.0978 & 2.06 \\
\hline OM09-58C-MS & 0.0148 & 1.66 & 0.0002 & 2.65 & 0.0111 & 3.12 \\
\hline \multirow[t]{3}{*}{ OM09-63C-MS } & 0.00003 & 4.47 & 0.00006 & 5.21 & 2.1948 & 6.86 \\
\hline & 0.00004 & 2.72 & 0.00008 & 1.54 & 1.8916 & 3.13 \\
\hline & 0.00003 & 3.59 & 0.00007 & 3.37 & 2.0121 & 4.99 \\
\hline OM10-52C-MG & 0.0003 & 2.08 & 0.0017 & 6.37 & 5.6094 & 6.70 \\
\hline \multicolumn{7}{|l|}{ Serpentines: } \\
\hline OM10-27C-MG-SERP & 0.00031 & 2.66 & 0.0003 & 2.06 & 1.0655 & 3.37 \\
\hline OM10-54C-MG-SERP & 0.00045 & 2.11 & 0.0009 & 1.53 & 2.0371 & 2.61 \\
\hline \multicolumn{7}{|l|}{ Sediments: } \\
\hline OM09-8S-MS & 0.1210 & 2.11 & 0.0686 & 2.35 & 0.5669 & 3.16 \\
\hline OM09-12S-MS & 0.9055 & 3.91 & 1.3124 & 6.66 & 1.4494 & 7.72 \\
\hline \multicolumn{7}{|l|}{ Carbonate Standard: } \\
\hline \multirow[t]{2}{*}{$\mathrm{JCp}-1$} & 2.7300 & 2.47 & 0.0502 & 3.36 & 0.0184 & 4.17 \\
\hline & 2.7503 & 1.51 & 0.0505 & 2.29 & 0.0184 & 2.74 \\
\hline
\end{tabular}




\begin{tabular}{|l|l|l|l|l|l|l|} 
& 2.7616 & 1.91 & 0.0510 & 2.17 & 0.0185 & 2.38 \\
\hline & 2.8075 & 2.55 & 0.0572 & 2.83 & 0.0204 & 3.81 \\
\hline & $\mathbf{2 . 7 6 2 3}$ & $\mathbf{2 . 1 1}$ & $\mathbf{0 . 0 5 2 2}$ & $\mathbf{2 . 6 6}$ & $\mathbf{0 . 0 1 8 9}$ & $\mathbf{3 . 2 8}$ \\
\hline
\end{tabular}




\begin{tabular}{|c|c|c|c|c|c|c|c|c|c|c|c|c|c|}
\hline Sample Name: & ${ }^{234} \mathbf{U} /{ }^{238} \mathbf{U}\left(\times 10^{-6}\right):$ & $\begin{array}{c}2 \sigma \\
(\%):\end{array}$ & ${ }^{230} \mathrm{Th} /{ }^{232} \mathrm{Th}\left(\mathrm{x} \mathrm{10^{-6 } ) :}\right.$ & $\begin{array}{c}2 \sigma \\
(\%):\end{array}$ & $\left({ }^{234} \mathbf{U} /{ }^{238} \mathbf{U}\right):$ & $\begin{array}{c}2 \sigma \\
(\%):\end{array}$ & $\left({ }^{230} \mathrm{Th} /{ }^{232} \mathrm{Th}\right):$ & $\begin{array}{c}2 \sigma \\
(\%):\end{array}$ & $\left({ }^{238} \mathrm{U} /{ }^{232} \mathrm{Th}\right):$ & $\begin{array}{c}2 \sigma \\
(\%):\end{array}$ & $\left({ }^{230} \mathrm{Th} /{ }^{238} \mathrm{U}\right):$ & $\begin{array}{c}2 \sigma \\
(\%):\end{array}$ & Uncorrected ${ }^{230}$ Th Age: \\
\hline \multicolumn{14}{|l|}{ Travertines: } \\
\hline OM09-76C-MS-A & 64.815 & 0.139 & 7.503 & 0.226 & 1.181 & 0.139 & 1.389 & 0.226 & 2.013 & 3.460 & 0.690 & 3.470 & 93,000 \\
\hline OM09-76C-MS-C & 64.296 & 0.205 & 6.344 & 0.335 & 1.172 & 0.205 & 1.174 & 0.335 & 1.252 & 2.579 & 0.938 & 2.600 & 163,000 \\
\hline OM09-8COPS-MS & 62.190 & 0.159 & 7.434 & 0.136 & 1.133 & 0.159 & 1.376 & 0.136 & 1.158 & 2.347 & 1.188 & 2.351 & -- \\
\hline OM09-84C-MS & 45.670 & 0.234 & 32.149 & 0.462 & 0.832 & 0.234 & 5.950 & 0.462 & 11.980 & 1.989 & 0.497 & 2.042 & 104,000 \\
\hline OM09-106C-MS-A & 63.466 & 0.048 & 20.330 & 0.098 & 1.156 & 0.048 & 3.763 & 0.098 & 8.606 & 5.765 & 0.437 & 5.766 & 51,000 \\
\hline \multirow[t]{3}{*}{ OM09-106C-MS-B } & 63.427 & 0.076 & 14.707 & 0.171 & 1.156 & 0.076 & 2.722 & 0.171 & 6.912 & 2.705 & 0.394 & 2.710 & \\
\hline & 63.390 & 0.079 & 14.693 & 0.090 & 1.155 & 0.079 & 2.719 & 0.090 & 6.956 & 2.258 & 0.391 & 2.260 & \\
\hline & 63.409 & 0.077 & 14.700 & 0.131 & 1.155 & 0.077 & 2.721 & 0.131 & 6.934 & 2.481 & 0.392 & 2.485 & 45,000 \\
\hline OM09-107C-MS & 68.860 & 0.064 & 23.603 & 0.082 & 1.255 & 0.064 & 4.369 & 0.082 & 4.294 & 1.963 & 1.017 & 1.964 & 164,000 \\
\hline OM09-109C-MS & 61.355 & 0.118 & 7.694 & 0.218 & 1.118 & 0.118 & 1.424 & 0.218 & 1.944 & 2.552 & 0.733 & 2.561 & 113,000 \\
\hline OM09-10COPS-MS & 61.451 & 0.081 & 7.649 & 0.153 & 1.120 & 0.081 & 1.416 & 0.153 & 1.476 & 2.178 & 0.959 & 2.183 & -- \\
\hline & & & & & & & & & & & & & \\
\hline & & & & & & & & & & & & & \\
\hline \multicolumn{14}{|l|}{ Mg-Rich Outcrop Veins: } \\
\hline OM09-47C-MS & 67.905 & 0.295 & 8.666 & 0.456 & 1.237 & 0.295 & 1.604 & 0.456 & 8.553 & 7.850 & 0.188 & 7.863 & 18,000 \\
\hline OM10-13C-MG & 67.111 & 0.187 & 31.111 & 0.800 & 1.223 & 0.187 & 5.758 & 0.800 & 18.024 & 4.782 & 0.319 & 4.848 & 33,000 \\
\hline OM10-53C-MG & 66.747 & 0.198 & 8.312 & 0.629 & 1.216 & 0.198 & 1.538 & 0.629 & 16.680 & 3.687 & 0.092 & 3.740 & 9,000 \\
\hline OM09-91C-MS & 66.866 & 0.129 & 12.481 & 0.356 & 1.218 & 0.129 & 2.310 & 0.356 & 11.551 & 15.393 & 0.200 & 15.397 & 19,000 \\
\hline OM10-82C-MG & 67.717 & 0.262 & -- & -- & 1.234 & 0.262 & -- & -- & 10.450 & 4.656 & -- & -- & -- \\
\hline OM10-84C-MG & 65.139 & 0.268 & 6.723 & 0.374 & 1.187 & 0.268 & 1.244 & 0.374 & 1.520 & 3.180 & 0.818 & 3.202 & 122,000 \\
\hline \multicolumn{14}{|l|}{ Mg-Rich Roadcut Veins: } \\
\hline OM09-35C-MS & -- & -- & 5.650 & 1.435 & -- & -- & 1.046 & 1.435 & 0.979 & 1.934 & 1.068 & 2.408 & -- \\
\hline OM09-55C-MS & 6.630 & 0.440 & 32.800 & 0.785 & 1.044 & 0.440 & 6.071 & 0.785 & 6.351 & 3.153 & 0.956 & 3.250 & 256,000 \\
\hline OM09-57C-MS & 31.344 & 0.109 & 164.870 & 0.151 & 1.010 & 0.109 & 30.515 & 0.151 & 31.019 & 2.055 & 0.984 & 2.061 & $>375,000$ \\
\hline OM09-58C-MS & 54.751 & 0.085 & -- & -- & 0.998 & 0.085 & -- & -- & 272.445 & 3.121 & -- & -- & -- \\
\hline OM10-52C-MG & 61.609 & 0.377 & 4.506 & 0.428 & 1.123 & 0.377 & 0.834 & 0.428 & 0.541 & 6.701 & 1.542 & 6.715 & Not Determinable \\
\hline \multicolumn{14}{|l|}{ Sediments: } \\
\hline OM09-8S-MS & 56.637 & 0.067 & 28.178 & 0.075 & 1.032 & 0.067 & 5.215 & 0.075 & 5.352 & 3.162 & 0.975 & 3.163 & -- \\
\hline OM09-12S-MS & 60.501 & 0.057 & 8.621 & 0.063 & 1.102 & 0.057 & 1.596 & 0.063 & 2.093 & 7.724 & 0.762 & 7.724 & -- \\
\hline
\end{tabular}




\begin{tabular}{|c|c|c|c|c|c|c|c|c|c|c|c|c|c|}
\hline Carbonate Sta & & & & & & & & & & & & & \\
\hline JCp-1 & 63.002 & 0.097 & 6.965 & 0.849 & 1.148 & 0.097 & 1.289 & 0.849 & 164.831 & 4.173 & 0.008 & 4.259 & \\
\hline & 62.943 & 0.080 & 7.016 & 0.430 & 1.148 & 0.080 & 1.299 & 0.430 & 165.235 & 2.740 & 0.008 & 2.773 & \\
\hline & 63.017 & 0.075 & 6.898 & 0.368 & 1.148 & 0.075 & 1.277 & 0.368 & 164.308 & 2.380 & 0.008 & 2.408 & \\
\hline & 62.899 & 0.048 & 7.107 & 0.420 & 1.146 & 0.048 & 1.315 & 0.420 & 148.854 & 3.809 & 0.009 & 3.832 & \\
\hline & 62.965 & 0.075 & 6.997 & 0.517 & 1.148 & 0.075 & 1.295 & 0.517 & 160.807 & 3.275 & 0.008 & 3.318 & \\
\hline
\end{tabular}

